\title{
A Highly Sensitive and Selective Spectrofluorimetric Method for the Determination of Arsenic at Pico-Trace Levels in Some Groundwater, Real, Environmental, Biological, Food and Soil Samples Using 2-( $\alpha$-Pyridyl)-Thioquinaldinamide
}

\author{
M. Jamaluddin Ahmed ${ }^{1 *}$, Ayesha Afrin ${ }^{1,2}$, Mamunur Rashid1 \\ ${ }^{1}$ Laboratory of Analytical Chemistry, Department of Chemistry, University of Chittagong, Chittagong, Bangladesh \\ ${ }^{2}$ Department of Applied Chemistry and Chemical Engineering, University of Chittagong, Chittagong, Bangladesh \\ Email: *pmjahmed55@gmail.com, ayeshaafrin@gmail.com, mamunurrashid2725@gmail.com
}

How to cite this paper: Ahmed, M.J., Afrin, A. and Rashid, M. (2019) A Highly Sensitive and Selective Spectrofluorimetric Method for the Determination of Arsenic at Pico-Trace Levels in Some Groundwater, Real, Environmental, Biological, Food and Soil Samples Using 2-( $\alpha$-Pyridyl)-Thioquinaldinamide. American Journal of Analytical Chemistry, 10, 316-347.

https://doi.org/10.4236/ajac.2019.108023

Received: June 22, 2019

Accepted: August 18, 2019

Published: August 21, 2019

Copyright $\odot 2019$ by author(s) and Scientific Research Publishing Inc. This work is licensed under the Creative Commons Attribution International License (CC BY 4.0).

http://creativecommons.org/licenses/by/4.0/

\section{cc) (i) Open Access}

\begin{abstract}
A very simple, ultra-sensitive, highly selective and non-extractive new spectrofluorimetric method for the determination of arsenic at pico-trace levels using 2-( $\alpha$-pyridyl)-thioquinaldinamide (PTQA) has been developed. PTQA has been proposed as a new analytical reagent for the direct non-extractive spectrofluorimetric determination of Arsenic (V). This novel fluorimetric reagent, PTQA becomes oxidized in a slightly acidic $\left(0.025-0.1 \mathrm{M} \mathrm{H}_{2} \mathrm{SO}_{4}\right)$ solution with Arsenic $(\mathrm{V})$ in absolute ethanol to produce highly fluorescent oxidized product $(\lambda \mathrm{ex}=303 \mathrm{~nm}$; $\lambda \mathrm{em}=365 \mathrm{~nm}$ ). Constant and maximum fluorescence intensities were observed over a wide range of acidity $(0.025-0.1 \mathrm{M}$ $\mathrm{H}_{2} \mathrm{SO}_{4}$ ) for the period between $2 \mathrm{~min}$ and $24 \mathrm{~h}$. Linear calibration graphs were obtained for $0.001-800-\mu g L^{-1}$ of As, having a detection limit of $0.1-\mathrm{ngL}^{-1}$; the quantification limit of the reaction system was found to be $1-\mathrm{ngL}^{-1}$ and the RSD was $0 \%-2 \%$. A large excess of over 60 cations, anions and complexion agents (like, chloride, phosphate, azide, tartrate, oxalate, SCN, etc.) do not interfere in the determination. The developed method was successfully used in the determination of arsenic in several Certified Reference Materials (alloys, steels, ores, human urine, hair, nails, bovine liver and sediments) as well as in some biological fluids (human blood, urine, hair, nail and milk), soil samples, food samples (vegetables, fruits, rice, corn and wheat), solutions containing both arsenic (III) and arsenic (V) speciation and complex synthetic mixtures. The results of the proposed method for assessing biological, food
\end{abstract}


and soil samples were comparable with both ICP-OES \& AHG-AAS and were found to be in excellent agreement.

\section{Keywords}

Spectrofluorimetry, Arsenic Determination, Groundwater, 2-( $\alpha$-Pyridyl)-thioquinaldinamide, Environmental, Biological, Soil, Food Samples

\section{Introduction}

The word "Arsenicosis" is unknown to the general people even a few days ago. But now-a-days maximum people of Bangladesh came to know from different sources that they have been suffering from a serious disease which is not due to virus but is metallic, the name of this metalloid is arsenic [1]. In October 1997, a survey conducted by Dhaka Community Hospital identified arsenic contamination in 59 districts where 60 million people are at risk. The water of shallow tube-wells in 59 districts showed arsenic contamination above $50 \mu \mathrm{gL} \mathrm{L}^{-1}$ (BSTI standard). According to the latest statistics of 64 districts of Bangladesh 61 districts contain arsenic [2] that one fifth of the population of our country is living on the edge [2], being exposed to arsenic contamination (WHO tolerance limit is $\left.10 \mu \mathrm{gL}^{-1}\right)$. However, all the investigations and studies signal arsenic contamination in groundwater of Bangladesh as "Disaster" [3].

The determination of arsenic (III) and arsenic (V) in environmental and biological systems is of considerable current interest because the toxicity of this element to aquatic and terrestrial organism including humans depends on its oxidation state [4]. Arsenic (V) is considered to be essential to mammals for the maintenance of growth, blood cells and normal iron metabolism [5], but arsenic (III) is reported to be toxic because of its complexation with coenzymes, coagulation of proteins and uncoupling of phosphorylation and its adverse impact on skin, liver, nose and throat [5]. Strong evidences were provided to indicate that arsenic in drinking water was responsible to cause skin, lung and bladder cancer [5]. Groundwater is the preferred source of drinking water for $99 \%$ people in the rural areas of Bangladesh. The provisional WHO guideline value of arsenic for drinking water is $10-\mu \mathrm{gL}^{-1}$. Therefore, extremely low concentrations of arsenic in groundwater used for potable and domestic purposes should be known accurately [3]. Hence, reliable methods are needed to check the arsenic status of a human and to monitor the occupational exposure to this element by measuring its concentration in bodily fluids.

In the expanding analytical fields such as environmental, biological and material monitoring of trace metals, there is an increasing need to develop simple, sensitive and selective analytical techniques that don't use expensive or complicated test equipment. Many sophisticated techniques, such as NAA, X-ray fluorescence, pulse polarography, ICP-OES, ICP-MS, GF-AAS, AHG-AAS and spectrophotometry have been used widely to the determination of arsenic. The first 
four methods are disadvantageous in terms of cost and the instruments used in routine analysis. GF-AAS is often lacking in sensitivity due to sublimation at high temperature, AHG-AAS is sensitive but often affected by matrix conditions of samples such as salinity. There is no direct spectrophotometric method for the determination of arsenic. Only one solvent extractive method is considered as standard method which uses Ag-diethyldithiocarbamate (Ag-DDTC) is very less sensitive [6]. ADDC is also insoluble in water but soluble in organic solvents such as pyridine and chloroform which are themselves carcinogenic according to EPA [7]. Spectrofluorimetry is essentially an ultra-trace analysis technique and is one of the most powerful and successful tools in chemical analysis. Spectrofluorimetry is extremely sensitive so much so that sometimes femtogram $\left(10^{-15} \mathrm{~g} \cdot \mathrm{g}^{-1}\right)$ per gram level or less can be determined [8].

The goal of the present work was to develop a simpler direct spectrofluorimetric method for the pico-trace determination of arsenic. In the search for a more sensitive reagent, in this work a new reagent was synthesized according to the method of Porter [9] and an oxidation reaction of 2-( $\alpha$-pyridyl)-thioquinaldinamide (PTQA); with $\mathrm{As}(\mathrm{V})$ and forms an intensely fluorescent oxidized product. Although PTQA has been reported to be spectrofluorimetric reagent for $\mathrm{Cr}(\mathrm{VI})$ [10], Se(IV) [11] and $\mathrm{Mn}(\mathrm{VII})$ [8] but has not previously been used for the spectrofluorimetric determination of arsenic. The method possesses distinct advantages over existing methods [12]-[32] with respect to sensitivity, selectivity, range of determination, simplicity, speed, $\mathrm{pH} /$ acidity range, thermal stability, accuracy, precision and ease of operation. The method is based on the oxidative reaction of non-fluorescent PTQA in a slightly acidic (0.025 - $\left.0.1 \mathrm{M} \mathrm{H}_{2} \mathrm{SO}_{4}\right)$ solution with $\mathrm{As}(\mathrm{V})$ in presence of ethanol to produce a highly fluorescent oxidized product, followed by a direct measurement of the fluorescence intensity in an aqueous solution at room temperature $\left(25^{\circ} \mathrm{C} \pm 5^{\circ} \mathrm{C}\right)$. Oxidation is very rapid, and no extraction is required. With suitable masking, the reaction can be made to be highly selective and the reagent blank solutions do not show any fluorescence.

\section{Materials and Methods}

\subsection{Apparatus}

A Shimadzu (Kyoto, Japan) (Model-RF-5301PC) Spectrofluorophotometer with $1-\mathrm{cm}$ quartz cells were used and a Jenway (England, UK) (Model-3010) pH meter with combination of electrodes were used for measurements of the fluorescence intensity and $\mathrm{pH}$. The calibration and linearity of the instrument were frequently checked with standard quinine sulfate $\left(10-\mathrm{mgL}^{-1}\right)$. A Shimadzu (Japan) (Model: 9800) Inductively Coupled Plasma-Optical Emission Spectrometer (ICP-OES), $\left[\lambda=418 \mathrm{~nm}\right.$, plasma gas flow rate $\left(\mathrm{Lmin}^{-1}\right)=15$, LOD: $1 \mu \mathrm{gL}^{-1}$ of As, RF Power $(\mathrm{W})=1400$, Nebulizer gas flow rate $\left.\left(\mathrm{Lmin}^{-1}\right)=1-10\right]$ and A Thermo Fisher Scientific (Model: ICE, origin USA) Atomic Absorption Spectrophotometer equipped with a microcomputer controlled Automated Hydride 
Generation along with Flow Injection (AHG-AAS). The arsenic was determined at 197.3-nm. The Elemental Analyzer (Exeter Analytical Inc. Model: CE 440) equipped with supersensitive thermal conductivity detector for simultaneous determination of CHN was used. Infrared spectrum was recorded with a FTIR Spectrophotometer, Shimadzu (Kyoto, Japan) (Model-IR Prestige 21, Detector DTGS $\mathrm{KBr}$ ) in the range $7500-350 \mathrm{~cm}^{-1}$ and Model: JEOL 500SS, magnetic field strength: $500 \mathrm{MHz}$, solvent used: DMSO D6, standard: TMS, four channel NMR spectrometer with signal-to-noise ratio of 5000:1 for proton were used for characterization of the ligand.

\subsection{Synthesis and Characterization of the Reagent}

\subsubsection{Synthesis of the Reagent}

2- $\left(\alpha\right.$-pyridyl)-thioquinaldinamide (PTQA, $\left.\mathrm{C}_{15} \mathrm{H}_{11} \mathrm{~N}_{3} \mathrm{~S}\right)$ (Molecular wt. $\left.=265.18\right)$ was synthesized according to the method of Porter [9]. The mixture containing 2-aminopyridine, quinaldine and Sulfur powder in the molar ratio of 2:1:1.5 were mixed and refluxed for 6 hours in $250-\mathrm{mL}$ round bottom flask fitted with bulb condenser under controlled temperature $(140-150)^{\circ} \mathrm{C}$ at $1 \mathrm{~atm}$. pressure over oil bath. The reaction mixture was kept overnight. The thiocompound was filtered and crystallized using petroleum ether $(60-80)^{\circ} \mathrm{C}$ to give a bright yellow crystalline (needle shaped) solid. The compound recrystallized from lime-distilled ethanol and was kept under vacuum $(0.1 \mathrm{~mm}$ of $\mathrm{Hg})$ for 24 hours. Yield of the product was $70 \%$. The structure of the reagent is shown in Figure 1.<smiles>Cc1ccc2ccccc2n1</smiles>

Quinaldine
$\mathrm{S}_{8}$

Sulphur powder<smiles>Nc1ccccn1</smiles>

2 - aminopyridine

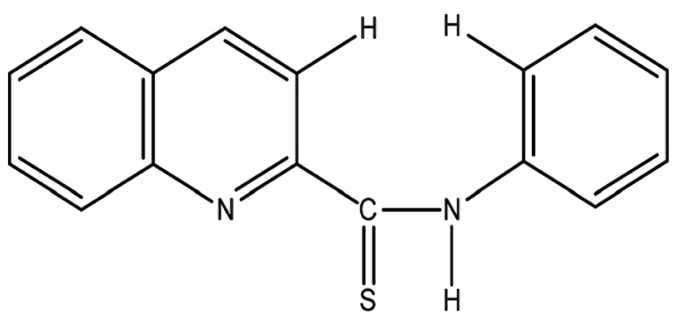

Figure 1. Reaction scheme of 2-( $\alpha$-pyridyl)-thioquinaldinamide (PTQA). 


\subsubsection{Characterization of the Reagent}

The reagent (PTQA) was characterized by taking the melting point, elemental analysis and an FTIR spectrum (Figure 2) and 1HNMR spectrum (Figure 3) and thermogravimetric analysis (Figure 4). The melting point of the synthesized compound (PTQA) was $155^{\circ} \mathrm{C} \pm 2^{\circ} \mathrm{C}$ (lit. $155^{\circ} \mathrm{C} \pm 1^{\circ} \mathrm{C}$ ) [8] which indicated the purity of PTQA. The results elemental analysis $(\mathrm{C}=72.25 \%, \mathrm{~N}=13.35 \%$ and $\mathrm{H}$ $=4.25 \%)$ of the reagent are very in good agreement with the calculated values $(\mathrm{C}$ $=72.43 \%, \mathrm{~N}=13.55 \%$ and $\mathrm{H}=4.55 \%$ ).

The FTIR spectrum of prepared reagent (PTQA) is shown in Figure 2. The presence of FTIR peak at $v^{\mathrm{C}^{-\mathrm{s}}}, 1126.43 \mathrm{~cm}^{-1}$ in Figure 2 was due to the characteristic $\mathrm{C}==\mathrm{S}$ double bond peak $\left(v^{\mathrm{C}=\mathrm{S}}, 1050-1200 \mathrm{~cm}^{-1}\right)[8]$ and $v^{\mathrm{C}-\mathrm{N}}, 1360 \mathrm{~cm}^{-1}$ was due the characteristics of C-N single bond peak $\left(v^{\mathrm{C}-\mathrm{N}}, 1350-1660 \mathrm{~cm}^{-1}\right)[8]$ of the reagent indicating the formation of PTQA. Both FTIR spectrum and elemental analysis data indicated the formation of the reagent PTQA. The formation of the reagent also tested by ${ }^{1}$ HNMR spectrum is shown in Figure 3. The steadiness of the thermo gravimetric curve (Figure 4) obtained for about $1 \mathrm{~g}$ of the reagent at $80^{\circ} \mathrm{C}-90^{\circ} \mathrm{C}$ indicated that the reagent did not contain any moisture.

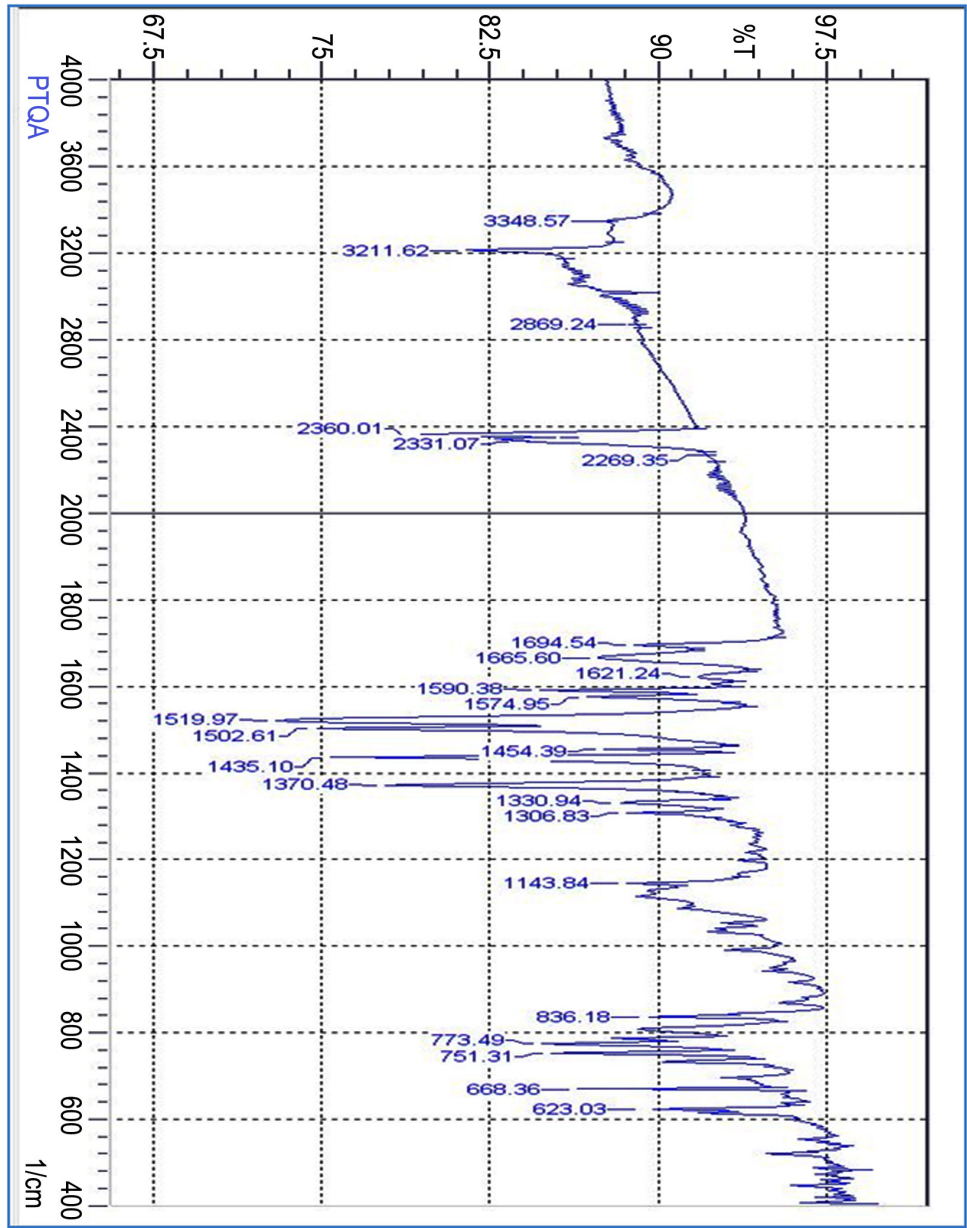

Figure 2. FTIR spectrum of 2-( $\alpha$-pyridyl)-thioquinaldinamide (PTQA). 


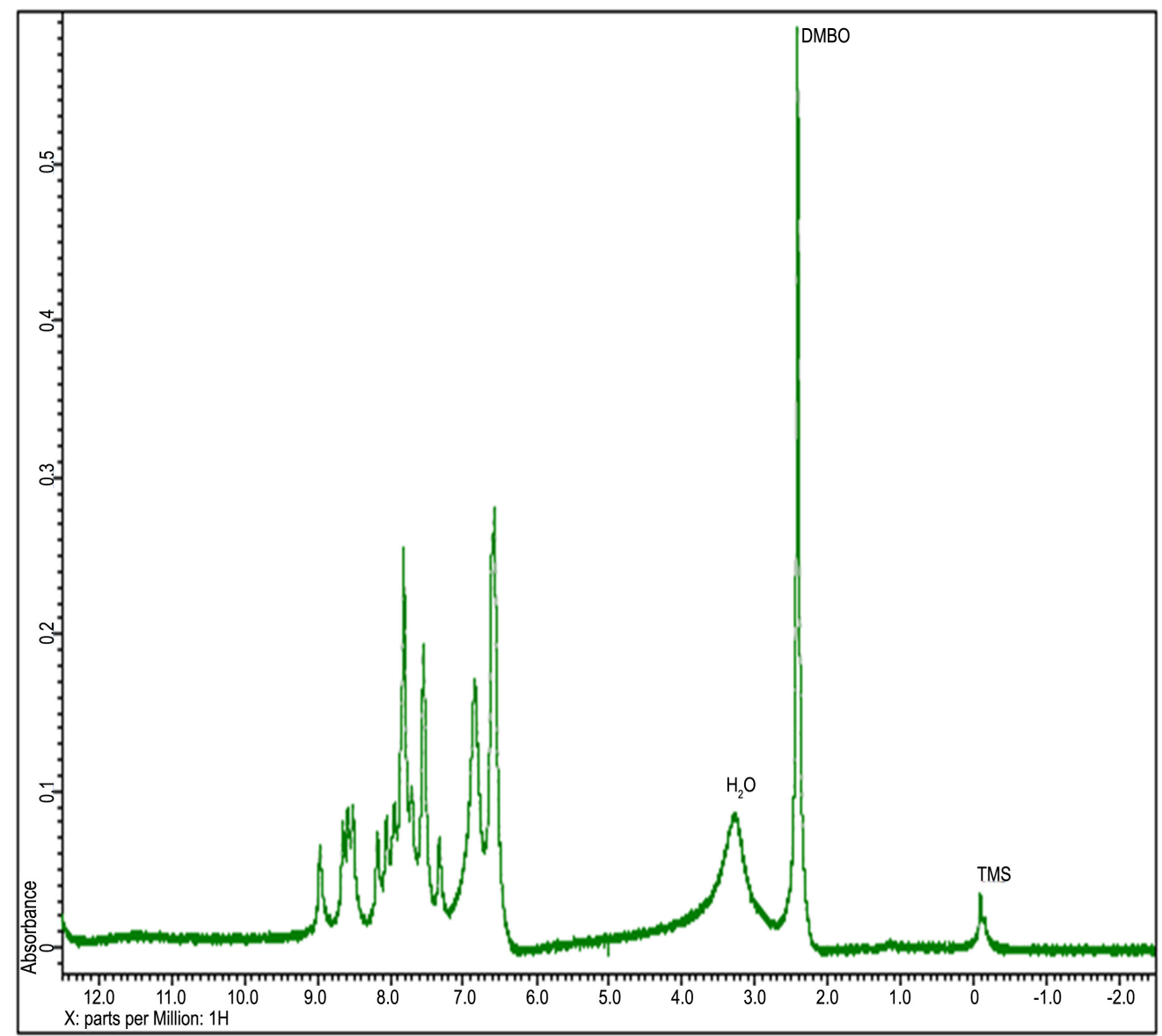

Figure 3. ${ }^{1} \mathrm{HNMR}$ spectrum of 2-( $\alpha$-pyridyl)-thioquinaldinamide (PTQA).

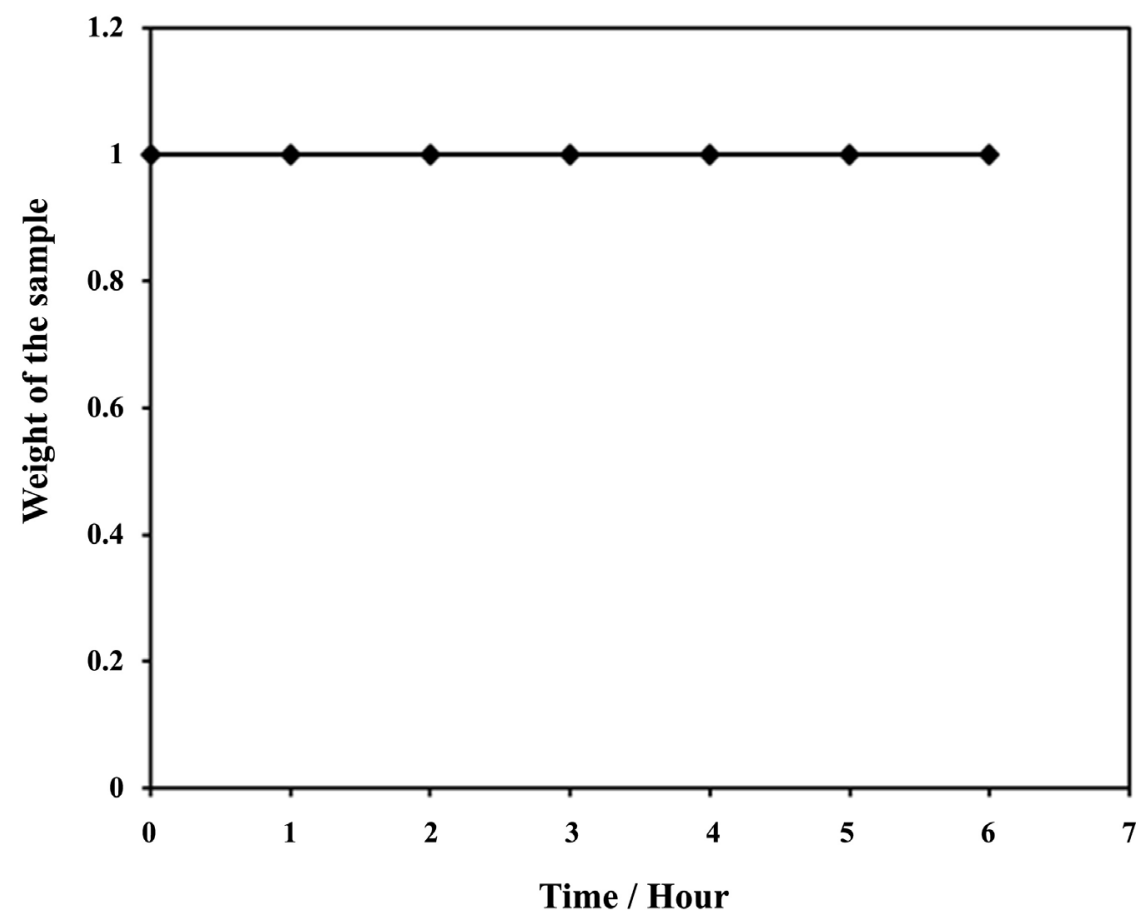

Figure 4. Thermogravimetric curve of 2 -( $\alpha$-pyridyl)-thioquinaldinamide at $80^{\circ} \mathrm{C}-90^{\circ} \mathrm{C}$. 
The elemental analysis was performed by the National Center of Excellence in Analytical Chemistry, University of Sindh, Pakistan and FTIR spectra was recorded with FTIR spectrophotometer, Shimadzu (Model-IR Prestige 21, Detector-DTGS KBR) in the range of $7500-350 \mathrm{~cm}^{-1}$ from our laboratory and ${ }^{1} \mathrm{HNMR}$ spectrum was recorded with 1HNMR spectrophotometer Model: JEOL 500SS from University of Kanazawa, Japan.

\section{Reagents and Solutions}

All the chemicals used were of analytical reagent grade of the highest purity available. High-purity absolute ethanol and high-purity de-ionized water were used throughout. High-purity water was obtained by passing tap water through cellulose absorbent and to mixed-bed ion exchange columns, followed by distillation in a corning AG-11 unit. Glass vessel were cleaned by soaking in acidified solutions of $\mathrm{KMnO}_{4}$ or $\mathrm{K}_{2} \mathrm{Cr}_{2} \mathrm{O}_{7}$ followed by washing with concentrated $\mathrm{HNO}_{3}$ and rinsed several times with high purity de-ionized water. Stock solutions and environmental water sample (1000-mL each) were kept in polypropylene bottles containing 1-mL concentrated $\mathrm{HNO}_{3}$. More rigorous contamination control was used when the arsenic levels in the specimens were low.

\subsection{PTQA Solution $\left(3.77 \times 10^{-3} \mathrm{M}\right)$}

The reagent solution was prepared by dissolving the requisite amount $(0.0026 \mathrm{~g})$ of PTQA, in a known volume $(10-\mathrm{mL})$ of absolute ethanol. A freshly prepared reagent solution $\left(3.77 \times 10^{-4} \mathrm{M}\right)$ was used whenever required.

\subsection{Arsenic (V) Standard Solution $\left(1.34 \times 10^{-2} \mathrm{M}\right)$}

A $100-\mathrm{mL}$ amount of stock solution $\left(1-\mathrm{mgmL}^{-1}\right)$ of pentavalent arsenic was prepared by dissolving $277.48 \mathrm{mg}$ of sodium arsenate $\left(\mathrm{Na}_{3} \mathrm{AsO}_{4}\right)$ (Sigma-Aldrich, Merck KGaA, Germany, pro-analysis grade, 99.6\%) in doubly distilled de-ionized water containing 3-mL of concentrated sulfuric acid. Aliquots of this stock solution were standardized by titrimetric method with ethylenediaminetetraacetic acid (EDTA) using $o$-phenanthroline solution (ferroin) as indicator [33]. More dilute standard solutions were prepared by appropriate dilution of aliquots from the stock solution with de-ionized water as and when required. A freshly standardized solution was always used.

\subsection{Arsenic (III) Standard Solution $\left(1.34 \times 10^{-2} \mathrm{M}\right)$}

A $100-\mathrm{mL}$ amount of stock solution $\left(1-\mathrm{mgmL}^{-1}\right)$ of trivalent arsenic was prepared by dissolving 173.5-mg of sodium arsenide $\left(\mathrm{NaAsO}_{2}\right)$ (Sigma-Aldrich, Merck KGaA, pro-analysis grade, 99.5\%) in doubly distilled de-ionized water and standardized by titrimetric method with ethylenediaminetetraacetic acid (EDTA) using $o$-phenanthroline solution (ferroin) as indicator [33]. More dilute standard solutions were prepared by appropriate dilution of aliquots from the stock solution with de-ionized water as and when required. A freshly standar- 
dized solution was always used.

\subsection{Potassium Dichromate Solution}

A $100-\mathrm{mL}$ amount of stock solution $(0.1 \mathrm{~N})$ was prepared by dissolving $500 \mathrm{mg}$ of finely powdered $\mathrm{K}_{2} \mathrm{Cr}_{2} \mathrm{O}_{7}$ (Merck) in $100-\mathrm{mL}$ de-ionized water.

\subsection{Ammonium Persulphate Solution}

Ammonium persulphate solution (2\% w/v) (A.C.S-grade $99 \%$ pure) was freshly prepared by dissolving $2 \mathrm{~g}$ in $100-\mathrm{mL}$ of de-ionized water.

\subsection{Tartrate Solution}

A $100-\mathrm{mL}$ stock solution of tartrate $(0.01 \% \mathrm{w} / \mathrm{v})$ was prepared by dissolving 10 $\mathrm{mg}$ of A.C.S.-grade (99\%) potassium sodium tartrate tetrahydrate in (100-mL) de-ionized water.

\subsection{Aqueous Ammonia Solution}

A $100-\mathrm{mL}$ solution of an aqueous ammonia solution was prepared by diluting 10 $\mathrm{mL}$ concentrated $\mathrm{NH}_{4} \mathrm{OH}(28 \%$ - 30\%, A.C.S.-grade) to $100-\mathrm{mL}$ with de-ionized water. The solution was stored in a polypropylene bottle.

\subsection{EDTA Solution}

A $100-\mathrm{mL}$ stock solution of EDTA $(0.01 \% \mathrm{w} / \mathrm{v})$ was prepared by dissolving 10-mg A.C.S.-grade (99\% pure) ethylenediaminetetraacetic acid as disodium salt dehydrate in $(100-\mathrm{mL})$ de-ionized water.

\subsection{Other Solutions}

Solutions of a large number of inorganic ions and complexing agents were prepared from their AnalaR grade or equivalent grade water-soluble salts (or the oxides and carbonates in hydrochloric acid); those of Niobium, Tantalum, Titanium, Zirconium and Hafnium were specially prepared from their corresponding oxides (Spec-pure, Johnson Matthey) according to the recommended procedures of Mukharjee [34]. In the case of insoluble substances, special dissolution methods were adopted [35].

\section{Procedure}

To 0.1 - 1.0-mL of a neutral aqueous solution containing 0.01 - 8000-ng of arsenic (V) in a 10-mL calibrated flask was mixed with a 1:400 - 1:1000 fold molar excess (preferably 1 -mL of $3.77 \times 10^{-3} \mathrm{M}$ of PTQA of the 2-( $\alpha$-pyridyl)-thioquinaldinamide (PTQA) reagent solution followed by the addition of $0.5-2-\mathrm{mL}$ (preferably $1-\mathrm{mL}$ ) of 0.5 $\mathrm{M}$ of sulfuric acid. The solution was mixed well and allowed to stand for $2 \mathrm{~min}$ after which $2-\mathrm{mL}$ of absolute ethanol was added and the mixture was diluted to the mark with de-ionized water. The fluorescence intensity of the system was measured at 365-nm against a corresponding reagent blank, prepared concur- 
rently, keeping the excitation wavelength maximum at $303-\mathrm{nm}$ and the instrument setting the same. The arsenic content in an unknown sample was determined using a concurrently prepared calibration graph.

\section{Sample Collection and Preservation}

\subsection{Environmental Samples}

Water and soil samples were collected in polythene bottles from different places of Bangladesh. After collection, $\mathrm{HNO}_{3}\left(1-\mathrm{mLL}^{-1}\right)$ was added as preservative.

\subsection{Blood, Urine and Milk}

Blood and urine samples were collected in polythene bottles from effected persons of Chittagong Medical College Hospital and Health Complex of Haji Ganja and Matlob Upajila of Chandpur District, Bangladesh. Milk sample was collected from a Bangladeshi lactating mother. Immediately after collection they were stored in a salt-ice mixture and later, at the laboratory, were at $-20^{\circ} \mathrm{C}$.

\subsection{Soil Samples}

Soil samples were collected from different locations of Bangladesh. Samples were dried in air and homogenized with a mortar.

\subsection{Food Samples}

Food samples (rice, wheat, fruits and vegetables) were collected from local market of Chittagong. After collection the samples (fruits and vegetables) were stored in refrigerator for preservation. Samples (rice, wheat) were used as dry condition and homogenized with a mortar.

\section{Results and Discussion}

\subsection{Factors Affecting the Fluorescence Intensity}

\section{Excitation and Emission Spectra}

$\mathrm{As}(\mathrm{V})$ fluoresces strongly in PTQA solution when irradiated with ultraviolet light. The excitation and emission spectra of the fluorescent As(V)-PTQA in $0.05 \mathrm{M}$ sulfuric acid medium was recorded using the spectrofluorophotometer. The excitation and emission maxima were at $303 \mathrm{~nm}$ and $365 \mathrm{~nm}$, respectively. The reagent blank exhibited negligible fluorescence, despite having wavelength maximum in the same region. In all instances, measurements were made against the reagent blank. The spectra are shown in Figure 5.

\subsection{Optimization of Some Parameters on the Fluorescence Intensity}

\subsubsection{Effect of Solvent}

Because PTQA is insoluble in water, an organic solvent was used for the system. Of the various solvents [chloroform, benzene, carbon tetrachloride, n-butanol, isobutanol, ethanol, 1, 4-dioxane and N,N-dimethylformamide (DMF)] were 




Figure 5. Spectra A \& B are the excitation spectra of As ${ }^{\mathrm{V}}$-PTQA system and reagent blank $(\lambda \mathrm{ex}=303 \mathrm{~nm})$, respectively; $\mathrm{C}$ and $\mathrm{D}$ are the corresponding emission spectra $(\lambda \mathrm{em}=365$ $\mathrm{nm})$ in aqueous solutions.

tested for the system, ethanol was found to be the best solvent for the system. The effect of ethanol on the fluorescence intensity was studied and no adverse effect was observed over a wide range $(15 \%-80 \%)$ of ethanol concentrations. It was observed that As (V)-PTQA system with $10-\mu g L^{-1}$ of $A s^{V}$ in absolute ethanol solution produced constant fluorescence intensity as shown in Figure 6. A concentration of $20 \% \mathrm{v} / \mathrm{v}$ ethanol in the final volume was enough to prevent any precipitation or turbidity and to allow accurate measurements. Therefore, a $20 \%$ $\mathrm{v} / \mathrm{v}$ ethanolic solution was used in the recommended procedure.

\subsubsection{Effect of Acidity}

The oxidation reaction was conducted in acid medium to avoid the precipitation of hydrated arsenic oxide. In order to determine the most suitable acid for the reaction, different acids (nitric, sulfuric, hydrochloric and phosphoric) were tested. But sulfuric acid was found to be the best acid than any other mineral acids for the system. The fluorescence intensity was at maximum and constant when the $10-\mathrm{mL}$ of solution $\left(10-\mu \mathrm{gL} \mathrm{L}^{-1}\right.$ of $\left.\mathrm{As}^{\mathrm{v}}\right)$ contained $0.5-2-\mathrm{mL}$ of $0.5 \mathrm{M}$ sulfuric acid at room temperature $(25 \pm 5)^{\circ} \mathrm{C}$. Outside this range of acidity, the fluorescence intensity decreased (Figure 7). The optimum acidity range in the final solution is therefore $0.025-0.1 \mathrm{M}$ (preferably $0.05 \mathrm{M}$ ) $\mathrm{H}_{2} \mathrm{SO}_{4}$. Therefore, $1-\mathrm{mL}$ of $0.5 \mathrm{M}$ sulfuric acid solution was used for all subsequent measurements. 


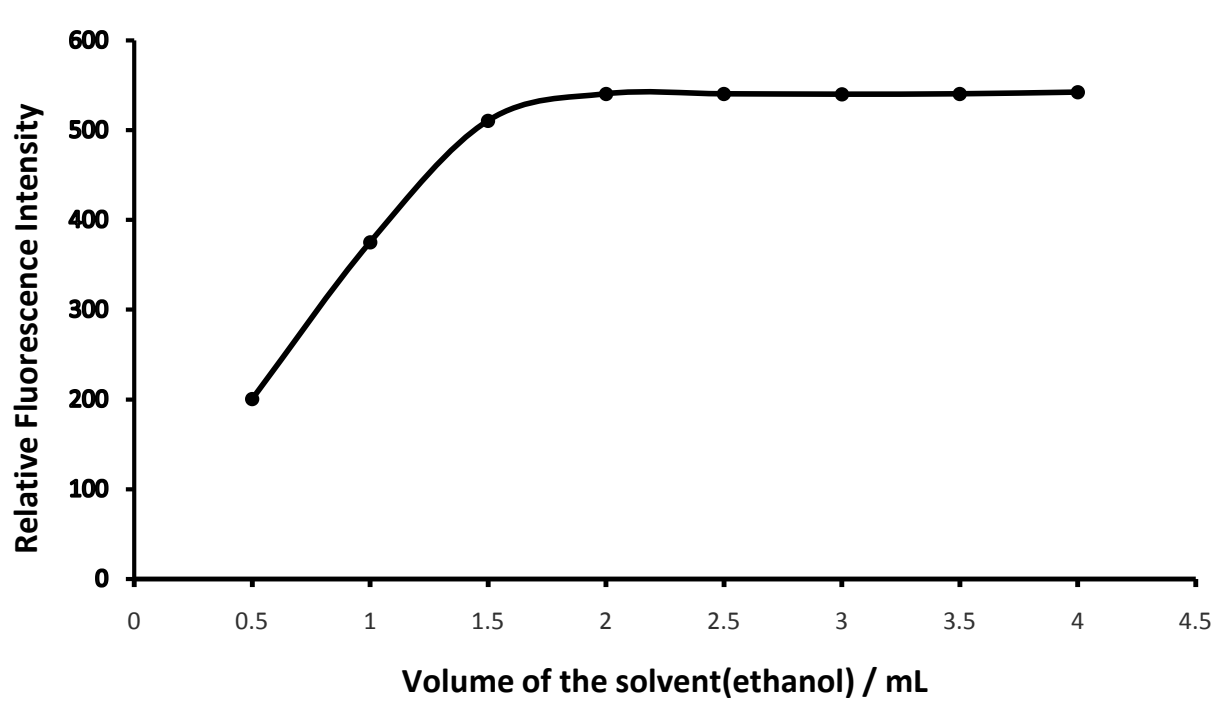

Figure 6. Effect of solvent (ethanol) on the fluorescence of As ${ }^{\mathrm{V}}$-PTQA system.

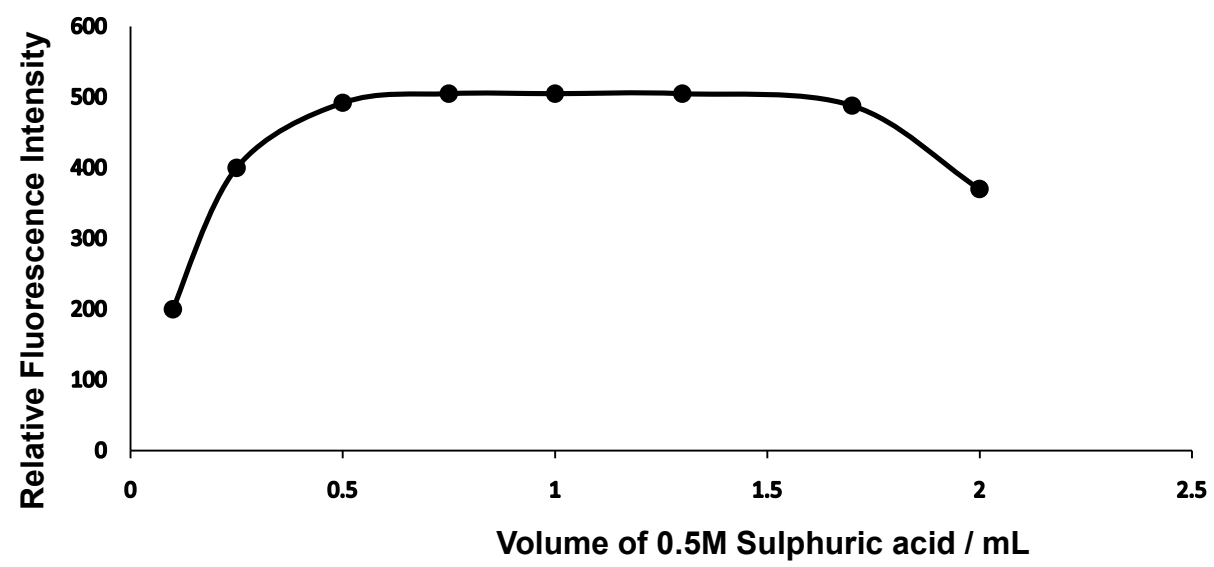

Figure 7. Effect of acidity on the fluorescence of $\mathrm{As}^{\mathrm{v}}$-PTQA system

\subsubsection{Effect of Temperature}

The influence of temperature was studied between $10^{\circ} \mathrm{C}-80^{\circ} \mathrm{C}$. It could be observed from Figure 8 that temperature effect is not pronounced between $10^{\circ} \mathrm{C}$ $80^{\circ} \mathrm{C}$ and so room temperature $(25 \pm 5)^{\circ} \mathrm{C}$ is recommended for all subsequent measurements.

\subsubsection{Effect of Time}

The reaction is instantaneous. The AsV-PTQA system attained maximum and constant fluorescence intensity immediately (within $2 \mathrm{~min}$ ) after dilution of the solution to the final volume, which then remained strictly unaltered for $24 \mathrm{~h}$ at room temperature $\left(25^{\circ} \mathrm{C} \pm 5^{\circ} \mathrm{C}\right)$ shown in Figure 9.

\subsubsection{Effect of Reagent Concentration}

The intensities of the fluorescence of a series of solutions containing a constant amount of $\mathrm{As}(\mathrm{V})$ with varying amounts of PTQA were measured in order to establish the optimum concentration of PTQA. The change of fluorescence intensity 


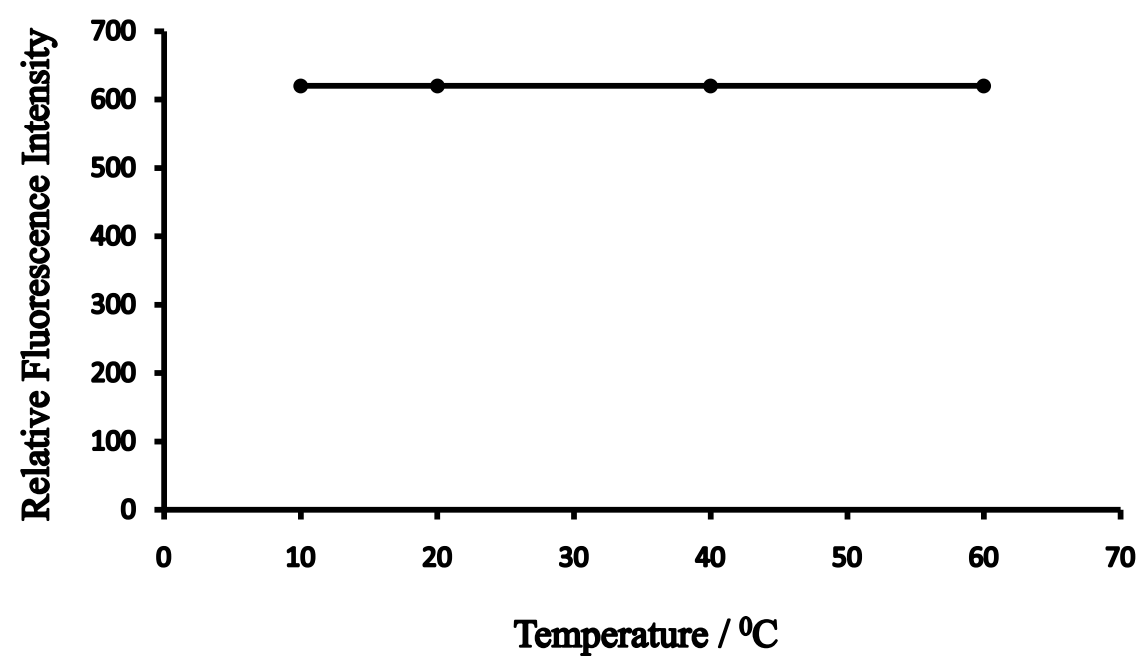

Figure 8. Effect of temperature on the fluorescence of $\mathrm{As}^{\mathrm{V}}$-PTQA system.

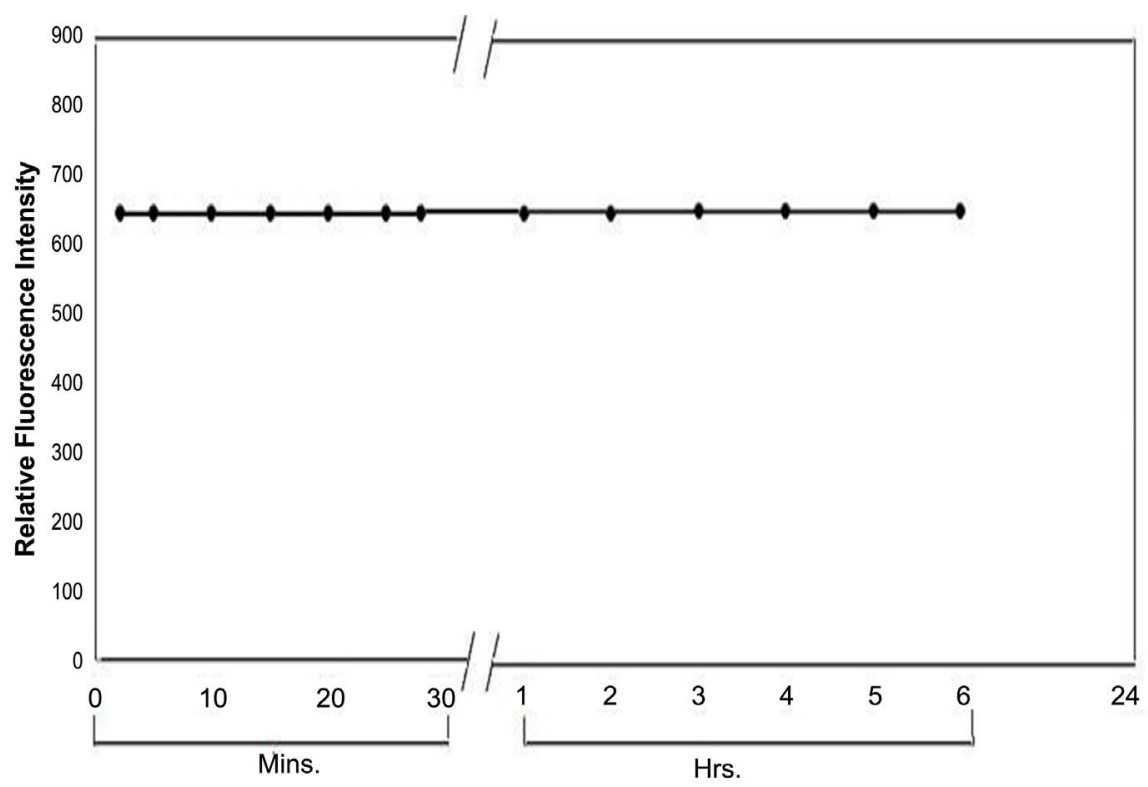

Time in minutes/hrs.

Figure 9. Effect of the time on the fluorescence of $\mathrm{As}^{\mathrm{V}}$-PTQA system.

with PTQA concentration was shown in Figure 10, while the concentration of $\mathrm{As}^{\mathrm{V}}$ was kept constant. It was found that the fluorescence intensity increases at first as the PTQA concentration rises and reaches a maximum, but further addition of PTQA hardly effect the intensity even PTQA is more times concentrated than $A s^{\mathrm{V}}$. It was observed that at $10-\mu \mathrm{gL}^{-1} \mathrm{As}^{\mathrm{V}}$ metal and the reagent molar ratios of 1:400 - 1:1000 produced a constant fluorescence intensity of the oxidized product. Outside this range of reagent, the fluorescence intensity gets decreased (Figure 10). At different $\mathrm{As}^{\mathrm{V}}$ concentrations $\left(0.5\right.$ and $\left.1-\mu \mathrm{gL}^{-1}\right)$, the effect of varying the reagent concentration was similar. For all subsequent measurements $1-\mathrm{mL}$ of $3.77 \times 10^{-3} \mathrm{M}$ of PTQA reagent was added. 


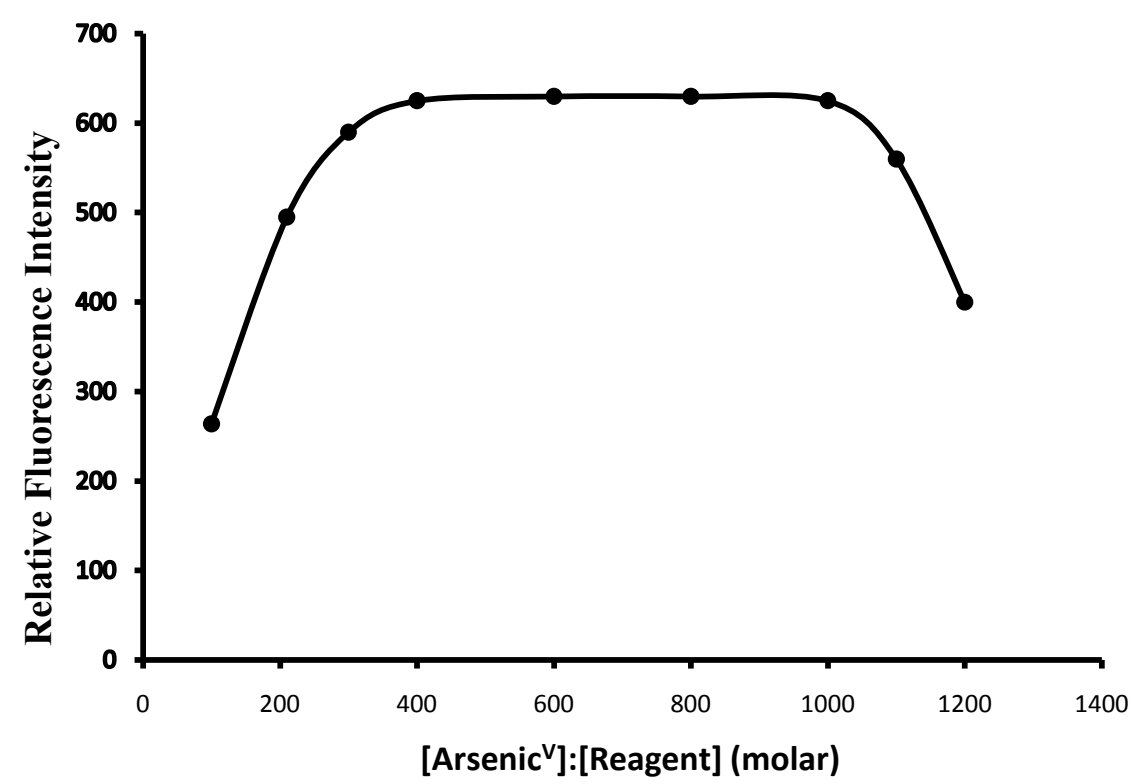

Figure 10. Effect of reagent (PTQA: arsenic ${ }^{\mathrm{V}}$ molar concentration ratio) on the fluorescence of arsenic $^{\mathrm{V}}$-PTQA system.

\subsubsection{Calibration Curves (Beer's Law)}

The calibration graphs for the determination of $\mathrm{As}(\mathrm{V})$ were constructed under optimum conditions. The well-known equation for spectrofluorimetric analysis in very dilute solutions derived from Beer's law. The effect of metal concentration was studied over $0.001-1000-\mu \mathrm{gL}^{-1}$ distributed in six different sets $(0.001$ $0.01,0.01-0.1,0.1-1,1-10,10-100$ and $\left.100-1000-\mu g L^{-1}\right)$ for convenience of measurement. The fluorescence intensity was linear over a wide range 0.001 $800-\mu \mathrm{gL}^{-1}$ of arsenic (V) at excitation wavelength at $303 \mathrm{~nm}$ and emission wavelength at $365 \mathrm{~nm}$ representing six linear graphs $(0.001-0.01,0.01-0.1,0.1-1.0$, $1-10,10-100$ and $\left.100-1000-\mu \mathrm{gL}^{-1}\right)$ as shown in Figures 11-16, respectively. Of six calibration graphs, the one showing the limit of the linearity range (Figure 16); the remaining five (Figures 11-15) were straight-line graphs passing through the origin $\left(\mathrm{R}^{2}=0.9998\right)$. The limit of detection and limit of quantization were found to be $0.1-\mathrm{ngL}^{-1}$ and $1-\mathrm{ngL}^{-1}$, respectively. The selected analytical parameters obtained with the optimization experiments are summarized in Table 1.

\subsection{Effect of Foreign Ions}

In order to apply the proposed method to the determination of the concentration of $\mathrm{As}(\mathrm{V})$ in the real sample, the effect of some co-existing species was investigated using $10-\mu \mathrm{gL}^{-1}$ of arsenic $(\mathrm{V})$. More than 60 anions, cations and complexing agents were studied individually to investigate their effect on the determination of $10-\mu g L^{-1}$ of arsenic $(\mathrm{V})$. The criterion for interference [36] was a fluorescence intensity value varying by more than $\pm 5 \%$ from the expected value for arsenic alone. The results are summarized in Table 2. As can be seen many ions have no significant effect on the determination of arsenic. The most serious interferences were from $\mathrm{Se}(\mathrm{IV}), \mathrm{Cr}(\mathrm{VI})$ and $\mathrm{Mn}(\mathrm{VII})$. 


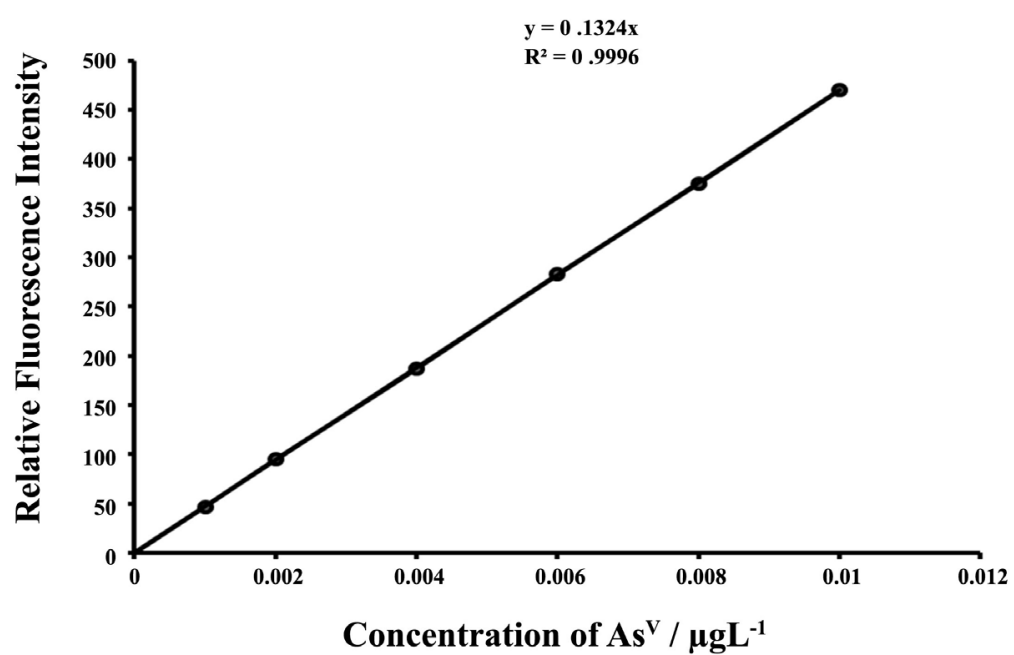

Figure 11. Calibration graph A: $0.001-0.01-\mu g L^{-1}$ of arsenic (V). Bandwidth: Ex. slit-1.5, Em. slit-3, Sensitivity: High.

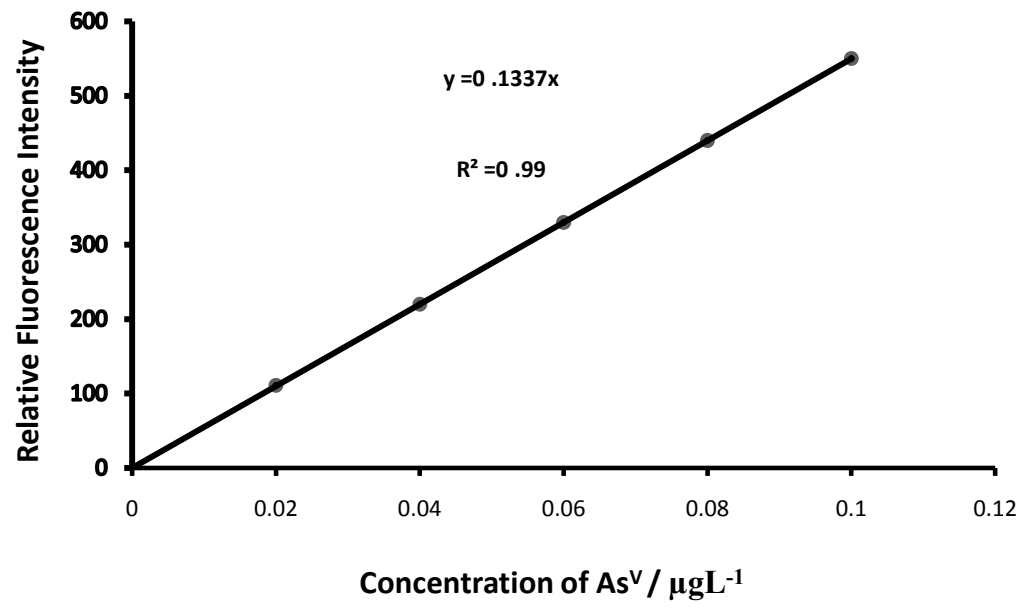

Figure 12. Calibration graph B: $0.01-0.1 \mu g L^{-1}$ of arsenic (V). Bandwidth: Ex. slit-3, Em. slit-1.5, Sensitivity: High.

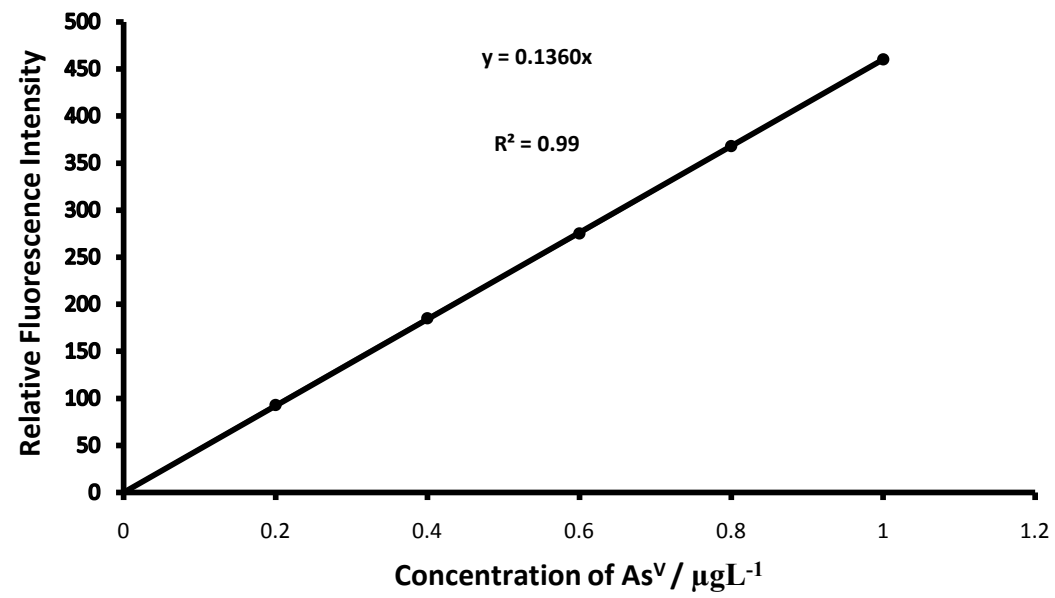

Figure 13. Calibration graph C: $0.1-1-\mu g L^{-1}$ of arsenic (V). Bandwidth: Ex. slit-3, Em. slit-3. Sensitivity: High. 


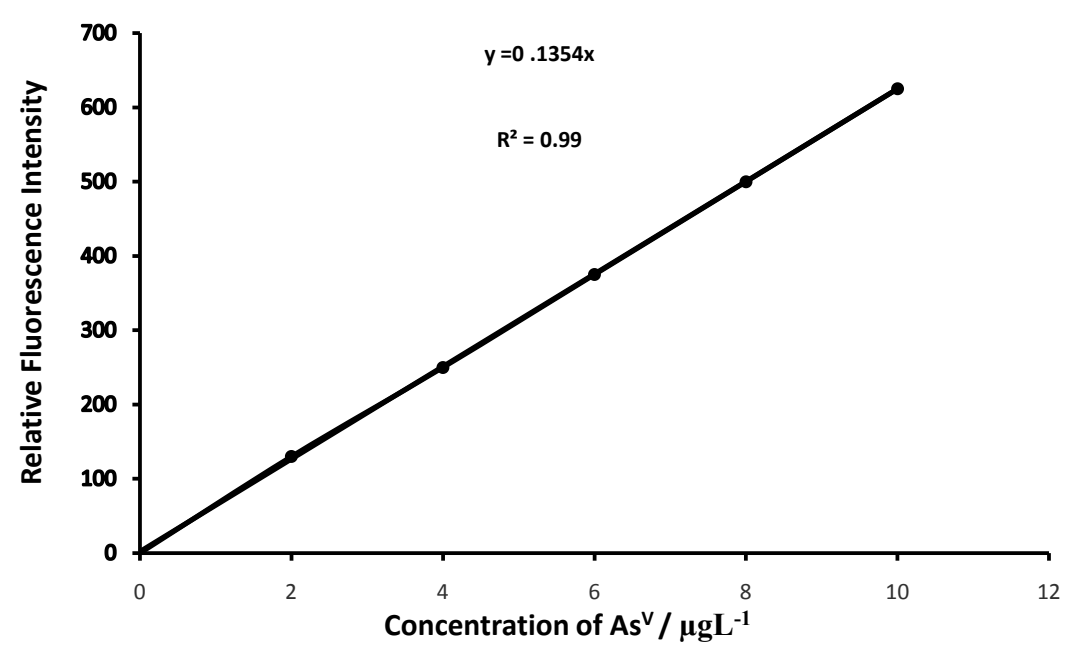

Figure 14. Calibration graph D: $1-10-\mu g L^{-1}$ of arsenic (V). Bandwidth: Ex. slit-5, Em. slit-1.5, Sensitivity: High.

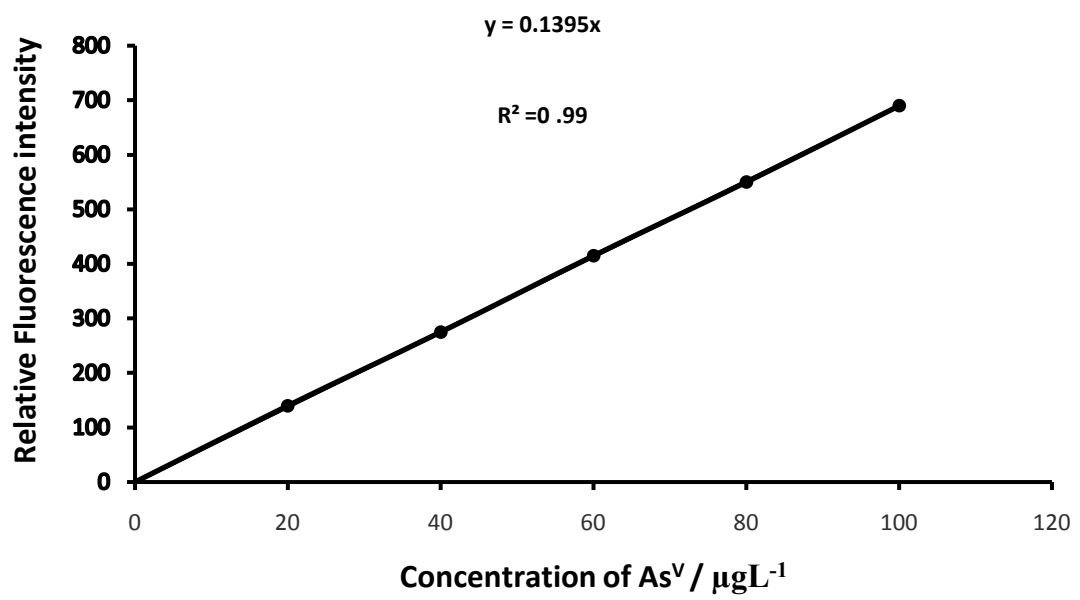

Figure 15. Calibration graph E: $10-100-\mu g L^{-1}$ of arsenic (V) Bandwidth: Ex. slit-1.5, Em. slit-5, Sensitivity: High.

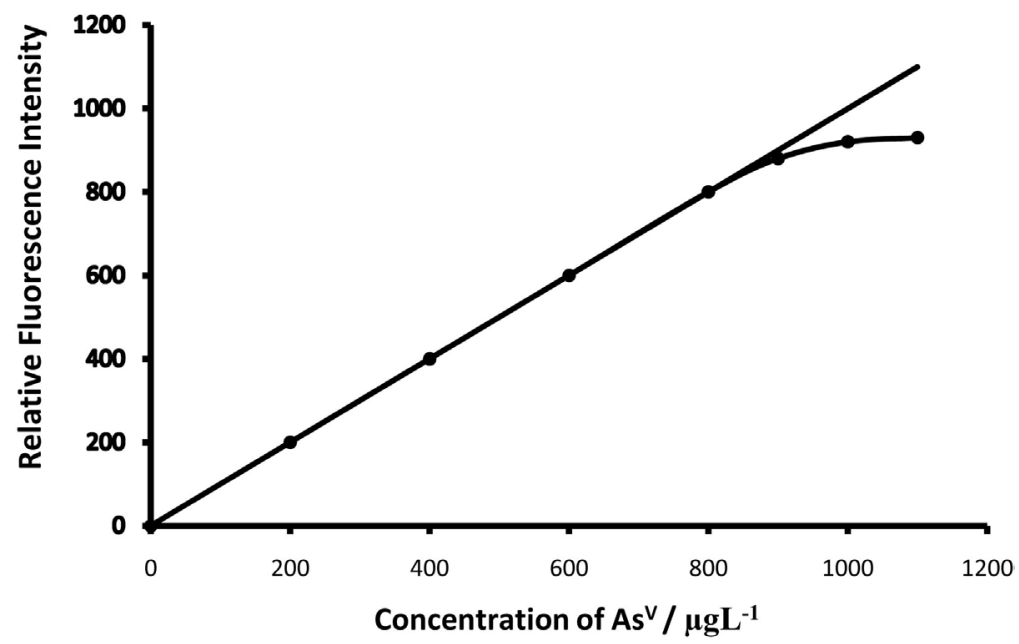

Figure 16. Calibration graph F: $100-800-\mu g L^{-1}$ of arsenic (V). Bandwidth: Ex. slit-1.5, Em. slit-1.5, Sensitivity: High. 
Table 1. Selected analytical parameters obtained with the optimization of experiments.

\begin{tabular}{|c|c|c|}
\hline Parameters & Studied Range & Selected Value \\
\hline Excitation wavelength maximum $/ \lambda_{\mathrm{ex}}(\mathrm{nm})$ & $200-700$ & 303 \\
\hline Emission wavelength maximum $/ \lambda_{\mathrm{em}}(\mathrm{nm})$ & $200-700$ & 365 \\
\hline Acidity $/ \mathrm{M} \mathrm{H}_{2} \mathrm{SO}_{4}$ & $0.001-0.1$ & $\begin{array}{c}0.025-0.1 \\
\text { (preferably } 0.05)\end{array}$ \\
\hline $\mathrm{pH}$ & $1.0-7.0$ & $\begin{array}{c}1.33-2.6 \\
\text { preferably } 2.0\end{array}$ \\
\hline Time/h & $0-72$ & $\begin{array}{c}1 \mathrm{~min}-24 \mathrm{~h} \\
\text { (preferably } 2 \mathrm{~min} \text { ) }\end{array}$ \\
\hline Temperature $/{ }^{\circ} \mathrm{C}$ & $5-80$ & $\begin{array}{c}10-70 \\
(\text { preferably } 25 \pm 5)\end{array}$ \\
\hline $\begin{array}{c}\text { Reagent } \\
\text { (fold molar excess, M:R) }\end{array}$ & $1: 50-1: 2000$ & $\begin{array}{c}\text { 1:400 - 1:1000 } \\
\text { (preferably 1:500) }\end{array}$ \\
\hline Linear range $/ \mu \mathrm{gL}^{-1}$ & $0.0001-1000$ & $0.001-800$ \\
\hline Limit of quantization $/ \mathrm{ngL}^{-1}$ & $0.01-100$ & 1 \\
\hline Detection limit $/ \mathrm{ngL}^{-1}$ & $0.001-10.0$ & 0.1 \\
\hline Reproducibility (\% RSD) & $0-10$ & $0-2$ \\
\hline Regression co-efficient $\left(\mathrm{R}^{2}\right)$ & $0.9996-0.9999$ & 0.9998 \\
\hline
\end{tabular}

Table 2. Table of tolerance limits of foreign ions $\mathrm{s}^{\mathrm{a}}$, tolerance ratio $\left[\operatorname{species}(\mathrm{x}) / \mathrm{As}^{\mathrm{V}}(\mathrm{w} / \mathrm{w})\right]$.

\begin{tabular}{|c|c|c|c|}
\hline Species & $\begin{array}{c}\text { Tolerance ratio } \\
\mathbf{x} / \mathrm{As}^{\mathrm{v}}(\mathrm{w} / \mathrm{w})\end{array}$ & Species & $\begin{array}{c}\text { Tolerance ratio } \\
\mathrm{x} / \mathrm{As}^{\mathrm{v}}(\mathrm{w} / \mathrm{w})\end{array}$ \\
\hline Aluminum & 1000 & Magnesium & 1000 \\
\hline Acetate & 1000 & Manganese (II) & 1000 \\
\hline Ammonium & 1000 & Manganese (VII) & $100^{c}$ \\
\hline Antimony & 1000 & Mercury (II) & 1000 \\
\hline Ascorbic acid & 5000 & Molybdenum (IV) & 1000 \\
\hline Azide & 1000 & Molybdenum (VI) & 1000 \\
\hline Barium & 1000 & Nitrate & 1000 \\
\hline Beryllium & 1000 & Nickel (II) & 1000 \\
\hline Bismuth & 1000 & Oxalate & 5000 \\
\hline Bromide & 1000 & Potassium & 1000 \\
\hline Cadmium & 1000 & Phosphate & 1000 \\
\hline Calcium & 1000 & Selenium (IV) & $100^{c}$ \\
\hline Carbonate & 1000 & Selenium (VI) & 1000 \\
\hline Cerium (IV) & 1000 & Sodium & 1000 \\
\hline Cerium (III) & 1000 & Strontium & 1000 \\
\hline Cesium & 1000 & Silver & 1000 \\
\hline Chloride & 1000 & Sulfate & 1000 \\
\hline Chromium (III) & 1000 & Tartrate & 5000 \\
\hline
\end{tabular}




\begin{tabular}{cccc} 
Continued & & & \\
\hline Chromium (VI) & $100^{\mathrm{b}}$ & Tellurium (IV) & 1000 \\
Cobalt (II) & 1000 & Titanium (IV) & 1000 \\
Cobalt (III) & 1000 & Thiosulfate & 1000 \\
Copper (II) & 1000 & Thiocyanate & 1000 \\
Cyanide & 1000 & Tin (II) & 1000 \\
Dichromate & 1000 & Tin (IV) & 1000 \\
EDTA & 5000 & Tungsten (VI) & 1000 \\
Fluoride & 1000 & Thiourea & 1000 \\
Iron(II) & 1000 & Uranium (VI) & 1000 \\
Iron (III) & 1000 & Vanadium (IV) & 1000 \\
Iodide & 1000 & Vanadium (V) & 1000 \\
Lithium & 1000 & Zinc & 1000 \\
\hline
\end{tabular}

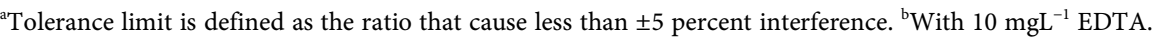
'With $10 \mathrm{mgL}^{-1}$ tartrate.

Most of the ions were tolerated over 1000 exceeds. Ascorbic acid, oxalate, citrate, tartrate, EDTA \& fluoride ions etc. were tolerated over 5000 folds. In order to eliminate the interference of $\mathrm{Se}(\mathrm{IV}), \mathrm{Cr}(\mathrm{VI})$ and $\mathrm{Mn}(\mathrm{VII})$ ions, EDTA and tartrate can be used as masking agents, respectively [37] A 100-fold excess of $\mathrm{Se}(\mathrm{IV}), \mathrm{Cr}(\mathrm{VI})$ and $\mathrm{Mn}(\mathrm{VII})$ ions could be masked with EDTA and tartrate, respectively. During the interference studies, if a precipitate was formed, it was removed by centrifugation. Strong reducing agents such as, tin(II), chloride, iron(II), sulfate, hydroxylamine, hydrochloride and sodium azide, which would otherwise reduce arsenic (V), undergo oxidation during the treatment of the arsenic (III) solution with persulfate and hence are not a problem [38]. The amount mentioned is not the tolerance limit, but the actual amount studied. However, for those ions whose tolerance limits have been studied, their tolerance ratios are mentioned in Table 2 .

\subsection{Precision and Accuracy}

The precisions of the present method were proved by measuring 10 solutions of same sample (each analyzed at least five times). The relative standard deviation $(\mathrm{n}=5)$ was $0 \%-2 \%$ for $0.01-8000-n g$ of arsenic $(\mathrm{V})$ in $10-\mathrm{mL}$, indicating that this method is highly precise and reproducible (Table 1 ). The detection limit $(3.3 \mathrm{~s} / \mathrm{S})$ and limit of quantization (10 times of detection limit) for arsenic (V) were found to be $0.1-\mathrm{ngL}^{-1}$ and $1-\mathrm{ng}^{-1}$, respectively. The method was also tested by analyzing several synthetic mixtures containing arsenic $(\mathrm{V})$ and diverse ions (Table 3). The results for total arsenic were in excellent agreement with certified values (Table 4). The reliability of our method was also tested by comparison results of groundwater conventional analyses (ICP-OES and AHG-AAS). The results of groundwater analyses by the spectrofluorimetric method were in 
Table 3. Determination of arsenic in some synthetic mixtures.

\begin{tabular}{|c|c|c|c|c|}
\hline \multirow[b]{2}{*}{ Sample } & \multirow{2}{*}{$\begin{array}{l}\text { Composition of Mixtures } \\
\qquad\left(\mu \mathrm{gL}^{-1}\right)\end{array}$} & \multicolumn{3}{|c|}{ Arsenic/ $\mu \mathrm{gL}^{-1}$} \\
\hline & & Added & $\begin{array}{l}\text { Found }^{\mathrm{a}} \\
(\mathrm{n}=5)\end{array}$ & $\begin{array}{l}\text { Recovery } \\
\pm \mathrm{SD}^{\mathrm{b}}(\%)\end{array}$ \\
\hline \multirow{2}{*}{ A } & \multirow{2}{*}{$\mathrm{As}^{\mathrm{V}}$} & 1.0 & 0.99 & $99 \pm 0.51$ \\
\hline & & 50 & 50.00 & $100 \pm 0.00$ \\
\hline \multirow{2}{*}{ B } & $\mathrm{As}$ in $\mathrm{A}+\mathrm{Cr}^{\mathrm{VI}}(50)+\mathrm{V}^{\mathrm{V}}(50)+$ & 1.0 & 1.00 & $100 \pm 0.00$ \\
\hline & $\mathrm{Fe}^{3}(50)+\mathrm{Ti}^{\mathrm{IV}}(50)+\operatorname{EDTA}(50)$ & 50 & 50.05 & $101 \pm 0.52$ \\
\hline \multirow{2}{*}{$\mathrm{C}$} & As in $\mathrm{B}+\mathrm{Pb}^{2+}(50)+\mathrm{Bi}^{3+}(50)+\mathrm{Se}^{\mathrm{IV}}$ & 1.0 & 0.98 & $98 \pm 0.68$ \\
\hline & $(50)+\mathrm{Hg}^{2+}(50)+\mathrm{Cu}^{2+}(50)$ & 50 & 49.50 & $99 \pm 0.92$ \\
\hline \multirow{2}{*}{$\mathrm{D}$} & As in $\mathrm{C}+\mathrm{Sb}^{3+}(50)+\mathrm{Ni}^{2+}(50)+$ & 1.0 & 0.98 & $98 \pm 1.0$ \\
\hline & $\mathrm{Ca}(50)+\mathrm{Cd}(50)+\mathrm{Te}^{\mathrm{IV}}(50)$ & 50 & 50.50 & $101 \pm 1.0$ \\
\hline \multirow{2}{*}{ E } & As in $\mathrm{D}+\mathrm{Mg}(50)+\mathrm{Mn}^{\mathrm{VII}}(50)+$ & 1.0 & 1.02 & $102.0 \pm 0.85$ \\
\hline & $\mathrm{W}^{\mathrm{VI}}(50)+\mathrm{Ba}(50)+\mathrm{Ag}(50)$ & 50 & 51.00 & $102.0 \pm 1.0$ \\
\hline \multirow{2}{*}{$\mathrm{F}$} & As in $\mathrm{E}+\mathrm{Zn}(50)+\mathrm{Na}(50)+$ & 1.0 & 1.05 & $105.0 \pm 1.5$ \\
\hline & $\mathrm{K}(50)+\mathrm{Ce}^{\mathrm{IV}}(50)+\mathrm{Ce}^{3+}(50)$ & 50 & 53.00 & $106.0 \pm 1.8$ \\
\hline
\end{tabular}

${ }^{a}$ Average of five analyses of each sample. ${ }^{\mathrm{b}}$ The measure of precision is the standard deviation (SD).

Table 4. Determination of arsenic in some certified reference materials.

\begin{tabular}{|c|c|c|c|c|}
\hline \multirow[b]{2}{*}{$\begin{array}{l}\text { Sample } \\
\text { No. }\end{array}$} & \multirow[b]{2}{*}{$\begin{array}{c}\text { Certified Reference Materials } \\
\text { (Composition, \%) }\end{array}$} & \multicolumn{3}{|c|}{ Arsenic (\%) } \\
\hline & & $\begin{array}{l}\text { In C.R.M } \\
\text { sample }\end{array}$ & $\begin{array}{l}\text { Found } \\
(n=5)\end{array}$ & $\mathrm{RSD}^{\mathrm{b}}$ \\
\hline 1 & $\begin{array}{l}\text { GBW01622: Unalloyed steel: } \mathrm{Ag}=0.3, \mathrm{As}=72, \mathrm{Bi}=0.5, \mathrm{Ca}=32, \mathrm{Cd}=1.9, \mathrm{Ga}=28 \\
\mathrm{In}=0.4, \mathrm{Mg}=53, \mathrm{~Pb}=2.2, \mathrm{Sb}=7.4, \mathrm{Se}=43, \mathrm{Sn}=0.164, \mathrm{Te}=0.5, \mathrm{Ti}=8.1, \mathrm{Zn}=6.8\end{array}$ & 72 & 70.95 & 1.5 \\
\hline 2 & $\begin{array}{c}\text { GBW01622: } \mathrm{Ag}=2.5, \mathrm{As}=96, \mathrm{Bi}=1.2, \mathrm{Ga}=38, \mathrm{~Pb} 4.75, \mathrm{Sb}=16, \mathrm{Se}=18, \mathrm{Te}=7.5 \\
\mathrm{Ti}=4.32, \mathrm{Zn}=14\end{array}$ & 96 & 95.85 & 2.0 \\
\hline 3 & $\begin{array}{c}\text { GBW01637: } \mathrm{Ag}=1, \mathrm{As}=14, \mathrm{Bi}=0.19, \mathrm{Ga}=34, \mathrm{In}=7.2, \mathrm{~Pb}=3.7, \mathrm{Sb}=3.3, \mathrm{Se}=12 \\
\mathrm{Sn}=8.3, \mathrm{Te}=31, \mathrm{Ti}=0.16, \mathrm{Zn}=13\end{array}$ & 14.00 & 15.96 & 1.2 \\
\hline 4 & $\begin{array}{l}\text { GBW01622: Unalloyed steel: } \mathrm{Ag}=0.3, \mathrm{As}=72, \mathrm{Bi}=0.5, \mathrm{Ca}=32, \mathrm{Cd}=1.9, \mathrm{Ga}=28 \\
\mathrm{In}=0.4, \mathrm{Mg}=53, \mathrm{~Pb}=2.2, \mathrm{Sb}=7.4, \mathrm{Se}=43, \mathrm{Sn}=0.164, \mathrm{Te}=0.5, \mathrm{Ti}=8.1, \mathrm{Zn}=6.8\end{array}$ & 72 & 70.95 & 1.5 \\
\hline 5 & NIES-CRM No. 18: Human urine ${ }^{a}$ & $0.134 \pm 0.01$ & $0.132 \pm 0.05$ & 0.06 \\
\hline 6 & NIST $^{\otimes}$ SRM-1577c: Bovine liver & $19.6 \pm 1.4^{\mathrm{c}}$ & $19.4 \pm 1.5$ & 1.5 \\
\hline 7 & NIST-CRM: Estuarian sediments solution & $10.00^{\mathrm{d}}$ & 9.99 & 0.5 \\
\hline 8 & NIST-SRM'-1643c: Human hair & $44.00 \pm 1.72^{\mathrm{c}}$ & $43.52 \pm 2.07$ & 2 \\
\hline 9 & NIST-SRM'-1643c: Human finger nails & $125.0^{c}$ & 124.8 & 2.5 \\
\hline 10 & SRM-NIST: Groundwater (HS Code: 382200 ) & $1.00^{\mathrm{e}}$ & 0.99 & 0.5 \\
\hline
\end{tabular}

a The CRMs were obtained from the National Research Council, Govt. Canada. ${ }^{b}$ The measure of precision is the relative standard deviation (RSD). ${ }^{c}$ values in $\mu \mathrm{gg}^{-1}$, ${ }^{\mathrm{d}}$ Values in $\mathrm{mgkg}^{-1}$, ${ }^{\mathrm{e}}$ Values in $\mathrm{mgL}^{-1}$.

excellent agreement with those obtained by ICP-OES and AHG-AAS (Table 5). The reliability of the procedure was tested by Recovery studies. The average percentage recovery obtained for addition of arsenic (V) spike to some environmental water samples was quantitative, as shown in Table 6. The results of biological analyses by the spectrofluorimetric method were excellent agreements with those obtained by AHG-AAS are shown in Table 7. The results of soil samples 
Table 5. Determination of arsenic in some groundwater samples of Bangladesh.

\begin{tabular}{|c|c|c|c|c|c|c|c|c|}
\hline \multirow{3}{*}{$\begin{array}{l}\text { Sample } \\
\text { ID }\end{array}$} & \multirow{3}{*}{ Sample Source } & \multicolumn{7}{|c|}{ Arsenic/mgL ${ }^{-1}$} \\
\hline & & \multicolumn{2}{|c|}{$\begin{array}{l}\text { Proposed Method } \\
(\mathrm{n}=5)\end{array}$} & \multirow{2}{*}{$\begin{array}{c}\text { Sample } \\
\text { Kit }\end{array}$} & \multicolumn{2}{|c|}{$\begin{array}{c}\text { ICP-OES } \\
(\mathrm{n}=5)\end{array}$} & \multicolumn{2}{|c|}{$\begin{array}{c}\text { AHG-AAS } \\
(\mathrm{n}=5)\end{array}$} \\
\hline & & Found $^{\mathrm{a}}$ & $\operatorname{RSD}^{\mathrm{b}}(\%)$ & & Found $^{\mathrm{a}}$ & $\operatorname{RSD}^{\mathrm{b}}(\%)$ & Found $^{\mathrm{a}}$ & $\operatorname{RSD}^{\mathrm{b}}(\%)$ \\
\hline 1 & Tap water & 0.055 & 0.5 & 0.00 & 0.048 & 0.8 & 0.04 & 0.06 \\
\hline 2 & Well water & 0.025 & 0.1 & 0.00 & 0.032 & 0.5 & 0.023 & 0.5 \\
\hline 3 & Shallow tube-well water & 1.15 & 1.0 & 1.0 & 1.05 & 1.2 & 1.11 & 1.1 \\
\hline 4 & Shallow tube-well water & 1.05 & 0.8 & 0.5 & 1.10 & 1.5 & 1.12 & 1.3 \\
\hline 5 & Shallow tube-well water & 0.85 & 0.6 & 0.5 & 1.0 & 0.9 & 1.95 & 0.5 \\
\hline 6 & Shallow tube-well water ${ }^{\mathrm{d}}$ & 1.90 & 1.0 & 2.0 & 1.85 & 1.5 & 1.88 & 1.2 \\
\hline 7 & Shallow tube-well water ${ }^{\mathrm{d}}$ & 1.12 & 1.0 & 1.2 & 1.20 & 1.1 & 1.15 & 1.5 \\
\hline 8 & Shallow tube-well water ${ }^{\mathrm{d}}$ & 0.52 & 1.0 & 0.5 & 0.58 & 1.2 & 0.60 & 1.2 \\
\hline 9 & Shallow tube-well water ${ }^{\mathrm{d}}$ & 0.05 & 1.1 & 0.05 & 0.03 & 0.5 & 0.05 & 1.0 \\
\hline 10 & Shallow tube-well water ${ }^{\mathrm{d}}$ & 2.55 & 1.5 & 2.2 & 2.24 & 1.5 & 2.58 & 1.5 \\
\hline 11 & Shallow tube-well water ${ }^{\mathrm{d}}$ & 0.03 & 0.5 & 0.00 & 0.05 & 0.6 & 0.04 & 0.5 \\
\hline 12 & Shallow tube-well water ${ }^{\mathrm{d}}$ & 3.35 & 1.5 & 3.0 & 3.40 & 1.6 & 3.40 & 1.8 \\
\hline 13 & Shallow tube-well water ${ }^{\mathrm{d}}$ & 0.03 & 0.00 & 0.00 & 0.00 & 0.00 & 0.00 & 0.00 \\
\hline 14 & Shallow tube-well water ${ }^{\mathrm{d}}$ & 0.82 & 0.5 & 0.5 & 0.85 & 0.6 & 0.88 & 0.8 \\
\hline 15 & Shallow tube-well water ${ }^{\mathrm{d}}$ & 0.04 & 0.8 & 0.00 & 0.00 & 0.00 & 0.03 & 0.5 \\
\hline 16 & Shallow tube-well water & 1.45 & 1.0 & 1.50 & 1.48 & 1.5 & 1.49 & 0.7 \\
\hline 17 & Shallow tube-well water & 1.25 & 1.0 & 1.0 & 1.35 & 1.0 & 1.30 & 0.8 \\
\hline 18 & Shallow tube-well water & 0.005 & 0.01 & 0.60 & 0.00 & 0.00 & 0.00 & 0.00 \\
\hline 19 & Shallow tube-well water & 0.79 & 0.5 & 0.5 & 0.75 & 0.8 & 0.82 & 0.7 \\
\hline 20 & Shallow tube-well water & 0.88 & 1.0 & 0.5 & 0.83 & 0.9 & 0.88 & 0.95 \\
\hline 21 & Shallow tube-well water & 0.56 & 0.5 & 0.5 & 0.83 & 0.8 & 0.61 & 0.5 \\
\hline 22 & Shallow tube-well water & 1.18 & 1.0 & 1.0 & 1.25 & 1.1 & 1.20 & 1.0 \\
\hline 23 & Shallow tube-well water & 0.05 & 0.5 & 0.00 & 0.56 & 1.2 & 0.58 & 1.0 \\
\hline 24 & Shallow tube-well water & 0.88 & 1.0 & 0.5 & 0.91 & 1.5 & 0.87 & 1.0 \\
\hline 25 & Shallow tube-well water & 0.06 & 0.5 & 0.00 & 0.06 & 0.8 & 0.08 & 0.8 \\
\hline
\end{tabular}

${ }^{\mathrm{a}}$ Average of five replicate determination of each sample, ${ }^{\mathrm{b}}$ The measure of precision is the relative standard deviation (RSD), ${ }^{\mathrm{c}}$ Shallow tube-well water from Mirsharai Upazila, Chattogram, ${ }^{\mathrm{d} S h a l l o w}$ tube-well water from Kachua Upazila, Chandpur, ${ }^{\mathrm{e} S h a l l o w}$ tube-well water from Matlab Upazila, Chandpur.

Table 6. Determination of arsenic in some environmental water samples.

\begin{tabular}{ccccc}
\hline \multirow{2}{*}{ Sample } & \multicolumn{2}{c}{${\text { Arsenic/ } \mu \mathrm{gL}^{-1}}^{\text {Recovery } \pm \mathbf{s}}$} & $\begin{array}{c}\mathbf{s}_{\mathbf{r}}^{\mathrm{b}} \\
(\%)\end{array}$ \\
\cline { 2 - 3 } & Added & Found $^{\mathrm{a}}$ & & \\
\hline Tap water & 0 & 27.5 & & \\
(Chattogram city) & 10 & 38.0 & $101.3 \pm 0.5$ & 0.25 \\
& 50 & 527.5 & $100 \pm 0.0$ & 0.00 \\
Rain water & 0 & 7.5 & & \\
(Chattogram city) & 10 & 17.5 & $100 \pm 0.0$ & 0.00 \\
& 50 & 520.0 & $102.5 \pm 1.0$ & 0.33 \\
\hline
\end{tabular}




\section{Continued}

\begin{tabular}{|c|c|c|c|c|c|}
\hline & lwater & 0 & 17.0 & & \\
\hline (Chatt & oram city) & 10 & 27.0 & $100 \pm 0.0$ & 0.00 \\
\hline & graint (ity) & 50 & 530.0 & $102.5 \pm 0.8$ & 0.35 \\
\hline & & 0 & 25.0 & & \\
\hline & Karnaphully & 10 & 35.5 & $101.4 \pm 0.7$ & 0.27 \\
\hline & & 50 & 75.0 & $100 \pm 0.0$ & 0.00 \\
\hline & & 0 & 30.5 & & \\
\hline & Karnaphully & 10 & 40.5 & $100 \pm 0.0$ & 0.00 \\
\hline & & 50 & 535.0 & $100.8 \pm 0.5$ & 0.19 \\
\hline & & 0 & 10.5 & & \\
\hline & (unner) & 10 & 20.5 & $100 \pm 0.0$ & 0.00 \\
\hline & & 50 & 62.5 & $103.3 \pm 0.8$ & 0.29 \\
\hline Sea water & & 0 & 12.0 & & \\
\hline & Bay of Bengle & 10 & 22.0 & $100 \pm 0.0$ & 0.00 \\
\hline & & 50 & 65.0 & $104.8 \pm 1.0$ & 0.45 \\
\hline & & 0 & 75.0 & & \\
\hline & 'T.S.P complex & 10 & 85.0 & $100 \pm 0.0$ & 0.00 \\
\hline & & 50 & 130.0 & $104 \pm 0.9$ & 0.48 \\
\hline & & 0 & 175.8 & & \\
\hline Drain water & ${ }^{\mathrm{d}} \mathrm{PHP}$ glass & 10 & 186.0 & $105.8 \pm 1.0$ & 0.55 \\
\hline & & 50 & 230.0 & $101.9 \pm 1.0$ & 0.49 \\
\hline & & 0 & 288.0 & & \\
\hline & ${ }^{\mathrm{e} B e r g e r}$ paint & 10 & 298.0 & $100 \pm 0.0$ & 0.00 \\
\hline & & 50 & 338.8 & $100.2 \pm 0.5$ & 0.15 \\
\hline
\end{tabular}

${ }^{\mathrm{a}}$ Average of five replicate determinations of each sample. ${ }^{\mathrm{b}}$ The measure of precision is the relative standard deviation $\left(\mathrm{S}_{\mathrm{r}}\right){ }^{\mathrm{C}}$ T.S.P Complex Ltd, Patenga, Chattogram. ${ }^{\mathrm{d}}$ PHP Glass factory, Chattogram. ${ }^{\mathrm{e}}$ Berger Paints Bangladesh Ltd., Kalurghat, Chattogram.

Table 7. Determination of arsenic in some human fluids, hair and nail samples.

\begin{tabular}{|c|c|c|c|c|c|c|}
\hline \multirow{3}{*}{$\begin{array}{l}\text { Sample } \\
\text { No }\end{array}$} & \multirow{3}{*}{ Sample Source ${ }^{a}$} & \multirow{3}{*}{ Sample } & \multicolumn{4}{|c|}{ Arsenic/mgL ${ }^{-1}$} \\
\hline & & & \multicolumn{2}{|c|}{$\begin{array}{l}\text { AHG-AAS } \\
(n=5)\end{array}$} & \multicolumn{2}{|c|}{$\begin{array}{l}\text { Proposed Method } \\
(n=5)\end{array}$} \\
\hline & & & Found & $\operatorname{RSD}(\%)^{b}$ & Found & $\operatorname{RSD}(\%)^{\mathrm{b}}$ \\
\hline \multirow[t]{2}{*}{1} & $\begin{array}{l}\text { Arsenicosis patient } \\
\text { (skin cancer) }\end{array}$ & Blood & 2.21 & 1.0 & 2.25 & 1.0 \\
\hline & (Male) & Urine & 0.58 & 0.8 & 0.62 & 0.5 \\
\hline \multirow[t]{2}{*}{2} & $\begin{array}{l}\text { Arsenicosis patient } \\
\text { (skin cancer) }\end{array}$ & Blood & 1.58 & 1.0 & 1.62 & 1.2 \\
\hline & (Male) & Urine & 0.35 & 0.5 & 0.41 & 0.8 \\
\hline \multirow[t]{2}{*}{3} & $\begin{array}{l}\text { Arsenicosis patient } \\
\text { (skin cancer) }\end{array}$ & Blood & 5.15 & 1.7 & 5.25 & 1.8 \\
\hline & (Male) & Urine & 1.36 & 1.1 & 1.42 & 1.0 \\
\hline \multirow{2}{*}{4} & Asthma & Blood & 0.85 & 1.0 & 0.92 & 1.0 \\
\hline & (Male) & Urine & 0.23 & 0.05 & 0.24 & 0.06 \\
\hline \multirow{2}{*}{5} & Liver cirrhosis & Blood & 1.25 & 1.0 & 1.28 & 1.1 \\
\hline & (Female) & Urine & 0.31 & 0.5 & 0.32 & 0.6 \\
\hline \multirow{2}{*}{6} & & Blood & 0.95 & 0.8 & 1.00 & 0.9 \\
\hline & Skin & Urine & 0.23 & 0.5 & 0.25 & 0.8 \\
\hline
\end{tabular}


Continued

\begin{tabular}{|c|c|c|c|c|c|c|}
\hline \multirow[b]{2}{*}{7} & Hypertension and & Blood & 1.35 & 1.0 & 1.42 & 1.1 \\
\hline & $\begin{array}{l}\text { Anemia } \\
\text { (Female) }\end{array}$ & Urine & 0.35 & 0.8 & 0.38 & 0.9 \\
\hline \multirow{2}{*}{8} & Normal Adult & Blood & 0.04 & 0.03 & 0.05 & 0.04 \\
\hline & (Male) & Urine & 0.01 & 0.005 & 0.01 & 0.005 \\
\hline 9 & $\begin{array}{c}\text { Arsenicosis patient } \\
\text { (Female) }\end{array}$ & Human hair & $11.51^{\mathrm{c}}$ & 1.5 & 11.65 & 1.8 \\
\hline 10 & $\begin{array}{c}\text { Arsenicosis patient } \\
\text { (Female) }\end{array}$ & Human nail & $7.5^{\mathrm{c}}$ & 1.0 & 7.04 & 1.2 \\
\hline 11 & $\begin{array}{c}\text { Arsenicosis patient } \\
\text { (Female) }\end{array}$ & Human milk & $24.8^{\mathrm{d}}$ & 1.0 & 24.6 & 1.1 \\
\hline
\end{tabular}

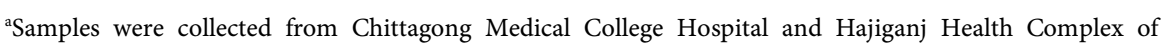
Chandpur, Bangladesh. ${ }^{b}$ Values in $\mu g^{-1}{ }^{c}$ Values in $\mathrm{mgkg}^{-1}$, ${ }^{\mathrm{d}}$ Values in $\mu \mathrm{gL}^{-1}$.

analyzed by the present method were found to be highly reproducible (Table 8). The results of food and vegetables analyses by spectrofluorimetric method were also found to be in excellent agreement with those obtained by ICP-OES (Table 9). The results of speciation of arsenic (III) and arsenic (V) in mixtures were highly reproducible (Table 10). Hence, the precision and accuracy of the method were found to be excellent.

\subsection{Nature of the Fluorescent Species}

The non-fluorescent reagent, PTQA, produced the same spectral characteristics with excitation and emission wavelengths almost invariably around $303 \mathrm{~nm}$ and $365 \mathrm{~nm}$, with arsenic (V), manganese (VII), chromium (VI), selenium (IV) and with persulfate, hydrogen peroxide, and triiodide in acidic media. This indicates that the fluorescence species is an oxidized product of the reagent itself and not a chelate. Similar oxidative fluorescent reactions have been utilized previously [7] [38]. The PTQA reagent produced here has so many potential reaction sites that the structure of the oxidized fluorescent species is difficult to predict. Given that ring closure can lead to intense fluorescent in some circumstances, it seems likely that photo-oxidative cyclization takes place, leading to the formation of structure (A) in resonance with structure (B) Figure 17.

\section{Applications}

The procedure was applied for determination of trace amounts of arsenic in some synthetic mixtures of various compositions (Table 3) and in several real samples, e.g. several Certified Reference Materials (CRM) (Table 4). The results of groundwater analyses by spectrofluorimetric method were found to be in excellent agreement with those obtained by ICP-OES and AHG-AAS (Table 5). The method was also extended to the determination of arsenic in several environmental, biological, soil, food, vegetables and fruit samples. In view of the unknown composition of environmental water samples, the same equivalent portions of each such sample were analyzed for arsenic content; the recoveries in 
Table 8. Determination of arsenic in some surface soil samples.

\begin{tabular}{cccc}
\hline Serial No. & Sample Source & Arsenic $\left(\mathrm{mgkg}^{-1}\right)^{\mathrm{a}}$ \\
$(\mathbf{n}=\mathbf{5})$ & RSD $^{\mathrm{b}}$ (\%) \\
\hline $\mathrm{S}_{1}$ & Fertilizer Industrial soil (T.S.P. Complex, Chittagong) & 25.15 & 1.5 \\
$\mathrm{~S}_{2}{ }^{\mathrm{c}}$ & Glass Industrial soil (PHP glass) & 7.20 & 1.8 \\
$\mathrm{~S}_{3}$ & Steel Industrial soil (Bangladesh Steel Re-rolling Mills & 3.82 & 1.3 \\
$\mathrm{~S}_{4}$ & Ltd., Chittagong, Bangladesh) & 3.75 & 1.5 \\
$\mathrm{~S}_{5}$ & Paint Industry soil (Berger paint) & 2.55 & 1.3 \\
$\mathrm{~S}_{6}$ & Paint Industry soil (Elite paint) & 0.85 & 1.2 \\
$\mathrm{~S}_{7}$ & Andustrial soil (Eastern Cables Ltd) & 0.29 & 0.5 \\
$\mathrm{~S}_{8}$ & Maricultural soil (Chittagong University Campus) & 0.25 & 0.05 \\
$\mathrm{~S}_{9}$ & Road side soil (Chittagong to Dhaka) & 1.55 & 0.5 \\
$\mathrm{~S}_{10}$ & Pharmaceutical soil (Glaxo Smith Kline) & 1.85 & 1.0 \\
\hline
\end{tabular}

${ }^{\mathrm{a}}$ Average of five analyses of each sample. ${ }^{\mathrm{b}}$ The measure of precision is the relative standard deviation (RSD). ${ }^{\mathrm{c} C o m p o s i t i o n ~ o f ~ t h e ~ s o i l ~ s a m p l e s: ~} \mathrm{C}, \mathrm{N}, \mathrm{P}, \mathrm{K}, \mathrm{Na}, \mathrm{Ca}, \mathrm{Mg}, \mathrm{Ce}, \mathrm{Cu}, \mathrm{Mo}, \mathrm{Fe}, \mathrm{Pb}, \mathrm{V}, \mathrm{Zn}, \mathrm{Mn}, \mathrm{Co}, \mathrm{NO}_{3}, \mathrm{SO}_{4}$ et al.

Table 9. Determination of arsenic in some food, fruit and vegetables samples.

\begin{tabular}{|c|c|c|c|c|c|c|}
\hline \multirow{3}{*}{$\begin{array}{l}\text { Serial } \\
\text { No. }\end{array}$} & \multirow{3}{*}{ Sample } & \multicolumn{4}{|c|}{$\begin{array}{c}\text { Arsenic/mgkg }{ }^{-1} \text { Found }{ }^{\mathrm{a}} \mathrm{s} \\
(\mathrm{n}=5)\end{array}$} & \multirow{3}{*}{$\begin{array}{l}\text { Sample } \\
\text { Source }\end{array}$} \\
\hline & & \multicolumn{2}{|c|}{$\begin{array}{l}\text { ICP-OES } \\
(\mathrm{n}=5)\end{array}$} & \multicolumn{2}{|c|}{$\begin{array}{l}\text { Proposed Method } \\
\qquad(\mathrm{n}=5)\end{array}$} & \\
\hline & & Found & $\mathrm{RSD}^{\mathrm{b}}$ & Found & $\mathrm{RSD}^{\mathrm{b}}$ & \\
\hline 1 & $\begin{array}{c}\text { Carrot } \\
\text { (Daucus carota) }\end{array}$ & 550.5 & 2.5 & 553.8 & 2.5 & $\begin{array}{c}\text { Local Market, } \\
\text { Chittagong }\end{array}$ \\
\hline 2 & Rice (Oryza sativa) & 100.0 & 1.5 & 102.0 & 1.6 & $\begin{array}{c}\text { Local Market, } \\
\text { Chittagong }\end{array}$ \\
\hline 3 & $\begin{array}{c}\text { Wheat } \\
\text { (Trictium aestivum) }\end{array}$ & 200.8 & 2.0 & 205.0 & 2.0 & $\begin{array}{c}\text { Local Market, } \\
\text { Chittagong }\end{array}$ \\
\hline 4 & $\begin{array}{c}\text { Corn } \\
\text { (Zea mays) }\end{array}$ & 418.0 & 2.4 & 421.5 & 2.5 & $\begin{array}{c}\text { Local Market, } \\
\text { Rajshahi }\end{array}$ \\
\hline 5 & $\begin{array}{c}\text { Mango } \\
\text { (Mangifera indica) }\end{array}$ & 48.5 & 1.5 & 49.8 & 2.0 & $\begin{array}{c}\text { Local Market, } \\
\text { Chittagong }\end{array}$ \\
\hline 6 & Arum(Arum discorides) & 510.5 & 2.0 & 512.0 & 2.1 & $\begin{array}{c}\text { Local Market, } \\
\text { Chittagong }\end{array}$ \\
\hline 7 & $\begin{array}{c}\text { Radish } \\
\text { (Raphanus sativas) }\end{array}$ & 483.5 & 2.0 & 485.0 & 2.5 & $\begin{array}{c}\text { Local Market, } \\
\text { Chittagong }\end{array}$ \\
\hline 8 & $\begin{array}{c}\text { Potato } \\
\text { (Solanum tuberosum) }\end{array}$ & 153.6 & 1.5 & 155.8 & 1.8 & $\begin{array}{c}\text { Local Market, } \\
\text { Chittagong }\end{array}$ \\
\hline 9 & $\begin{array}{c}\text { Spinach } \\
\text { (Spinacia oleracea) }\end{array}$ & 192.8 & 2.1 & 195.2 & 2.0 & $\begin{array}{c}\text { Local Market, } \\
\text { Chittagong }\end{array}$ \\
\hline 10 & $\begin{array}{c}\text { Cabbage } \\
\text { (Brassica oleracea) }\end{array}$ & 289.0 & 2.5 & 290.5 & 2.8 & $\begin{array}{c}\text { Local Market, } \\
\text { Chittagong }\end{array}$ \\
\hline
\end{tabular}

${ }^{a}$ Average of five replicate analyses of each sample. ${ }^{b}$ The measure of precision is the relative standard deviation (RSD). 
Table 10. Determination of arsenic (III) and arsenic (V) in mixtures.

\begin{tabular}{|c|c|c|c|c|c|c|c|}
\hline \multirow{2}{*}{$\begin{array}{l}\text { Serial } \\
\text { No. }\end{array}$} & \multirow{2}{*}{$\begin{array}{c}\text { As(III): } \\
\text { As(V) }\end{array}$} & \multicolumn{2}{|c|}{$\begin{array}{c}\text { As, taken } \\
\left(\mu \mathrm{gL}^{-1}\right)\end{array}$} & \multicolumn{2}{|c|}{$\begin{array}{c}\text { As, found } \\
\left(\mu \mathrm{gL}^{-1}\right)\end{array}$} & \multicolumn{2}{|c|}{$\begin{array}{l}\text { Error } \\
\left(\mu \mathrm{gL}^{-1}\right)\end{array}$} \\
\hline & & $\operatorname{As}(\mathrm{V})$ & As(III) & $\operatorname{As}(\mathrm{V})$ & As(III) & $\operatorname{As}(\mathrm{V})$ & As(III) \\
\hline 1 & $1: 1$ & 10 & 10 & 9.98 & 9.99 & 0.02 & 0.01 \\
\hline 1 & $1: 1$ & 10 & 10 & 10.00 & 10.02 & 0.00 & 0.02 \\
\hline \multirow[t]{2}{*}{1} & $1: 1$ & 10 & 10 & 9.97 & 9.98 & 0.03 & 0.02 \\
\hline & \multicolumn{3}{|c|}{ Mean error: $\mathrm{As}(\mathrm{V})= \pm 0.017$} & Standard deviation: $\mathrm{As}(\mathrm{V})= \pm 0.012$ & \multicolumn{2}{|c|}{$\operatorname{As}(\mathrm{III})= \pm 0.017$} & \\
\hline 1 & $1: 5$ & 10 & 50 & 9.98 & 49.70 & 0.03 & 0.30 \\
\hline 1 & $1: 5$ & 10 & 50 & 9.99 & 49.80 & 0.01 & 0.20 \\
\hline \multirow[t]{2}{*}{1} & $1: 5$ & 10 & 50 & 9.98 & 49.80 & 0.02 & 0.20 \\
\hline & \multicolumn{4}{|c|}{ Mean error: $\mathrm{As}(\mathrm{V})= \pm 0.017$} & \multicolumn{2}{|c|}{$\operatorname{As}(\mathrm{III})= \pm 0.234$} & \\
\hline 1 & $1: 10$ & 10 & 100 & 9.99 & 99.8 & 0.01 & 0.2 \\
\hline 1 & $1: 10$ & 10 & 100 & 9.98 & 99.9 & 0.02 & 0.1 \\
\hline \multirow[t]{2}{*}{1} & $1: 10$ & 10 & 100 & 9.97 & 99.8 & 0.03 & 0.2 \\
\hline & \multicolumn{4}{|c|}{ Mean error: $\mathrm{As}(\mathrm{V})= \pm 0.02$} & $\mathrm{As}(\mathrm{III})= \pm 0.0018$ & & \\
\hline
\end{tabular}<smiles>S=C(Nc1ccccn1)c1ccc2ccccc2n1</smiles>

2-( $\alpha$-pyridyl)-thioquinaldinamide

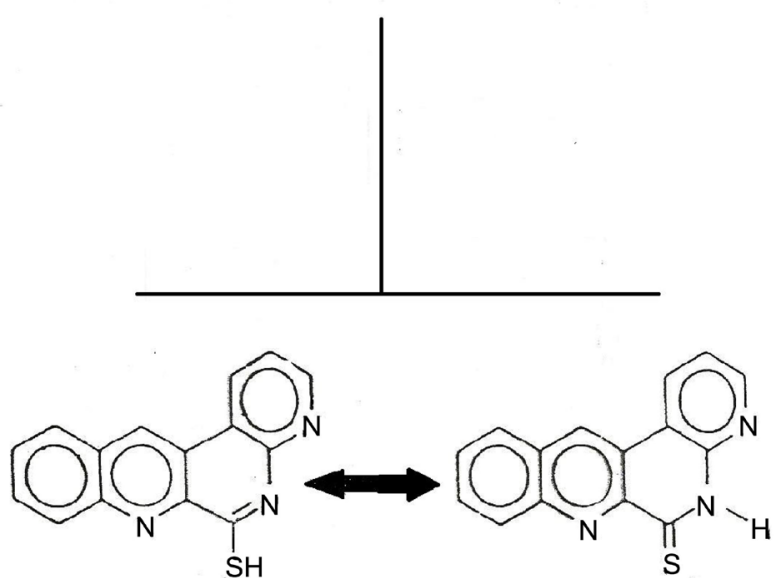

(A)

(B)

Figure 17. Mechanism of oxidative cyclization reaction of 2-( $\alpha$-pyridyl)-thioquinaldinamide (PTQA).

both the "spiked" (added to the samples before the mineralization or dissolution) and the "unspiked" samples are in excellent agreement (Table 6). The re- 
sults of biological analyses by the spectrofluorimetric method were found to be excellent agreement with those obtained by AHG-AAS which is shown in Table 7. The results of soil samples by the spectrofluorimetric method are shown in Table 8. The results of food and vegetables analyses by spectrofluorimetric method were also found to be in excellent agreement with those obtained by ICP-OES (Table 9). The results of speciation of arsenic (III) and arsenic (V) in mixtures were highly reproducible (Table 10).

\subsection{Determination of Arsenic in Synthetic Mixtures}

The procedure was applied to determine trace amounts of arsenic (V) in some synthetic mixtures with good recovery being achieved. The result indicates the proposed method is suitable and can be successfully applied for determination of arsenic (V). Several synthetic mixtures of varying compositions containing arsenic (V) and diverse ions of known concentrations were determined by the present method using EDTA as masking agent. The results were found to be highly reproducible as shown in Table 3. Accurate recoveries were achieved in all solutions in the range $99.6 \pm 1.5$ to $99.9 \pm 0.6$. The reliability of our arsenic-PTQA oxidation procedure was approved by quantitative recovery of arsenic $(\mathrm{V})$ spiked in several synthetic mixtures containing arsenic $(\mathrm{V})$ and diverse ions. This method has high precision and accuracy $\left(s= \pm 0.01\right.$ for $\left.0.5-\mu g L^{-1}\right)$.

\subsection{Determination of Arsenic in Certified Reference Materials}

A 0.1-g amount of an alloy or steel sample containing $1 \%-96 \%$ of arsenic was weighed accurately and placed in a 50-mL Erlenmeyer flask in presence of excess oxidizing agent to oxidize arsenic (III) to arsenic (V) following a method recommended by Mitra [39]. To it, $10-\mathrm{mL}$ of $20 \%$ (w/v) sulfuric acid was added and while carefully covering with a watch glass until the brisk reaction subsided. The solution was heated and simmered gently after the addition of $10-\mathrm{mL}$ of concentrated $\mathrm{HNO}_{3}$ until all residual carbides were decomposed. Then a further 2-mL of $1+1 \mathrm{H}_{2} \mathrm{SO}_{4}$ and 2-mL 2\% (w/v) freshly prepared persulfate were added and the solution was evaporated carefully to dense white fumes of sulfur trioxide, then cooled to room temperature $\left(25^{\circ} \mathrm{C} \pm 5^{\circ} \mathrm{C}\right)$. After suitable dilution with de-ionized water, the contents of the Erlenmeyer flask were warmed to dissolve the soluble salts. The solution was then cooled and neutralized with dilute $\mathrm{NH} 4 \mathrm{OH}$ in presence of $1-2-\mathrm{mL}$ of $0.01 \%(\mathrm{w} / \mathrm{v})$ EDTA solution. The resulting solution was filtered if necessary, through a Whatman No. 40 filter paper into a $100-\mathrm{mL}$ calibrated flask. The residue (silica and tungstenic acid) was washed with a small volume of hot $1+99 \mathrm{H}_{2} \mathrm{SO}_{4}$, followed by water; the volume was made up to mark with de-ionized water.

A suitable aliquot $(1-2-\mathrm{mL})$ of the above-mentioned solution was taken into a $10-\mathrm{mL}$ calibrated flask and the arsenic (V) content was determined; as described under procedure using tartrate or EDTA as masking agent. The proposed procedure for the spectrofluorimetric determination of arsenic was applied to the analy- 
sis of single element CRM of As SRM-NIST:Ground water (HS Code: 382200), NIES-CRM No. 18: Human urine), NIST ${ }^{\oplus}$ SRM-1577c: Bovine liver, CRM-Estuarian sediments solution, NIST-SRM ${ }^{\circ}-1643$ c: Human finger nails. NIST-CRMs are obtained from the National Research Council, Govt. of Canada using tartrate or EDTA as masking agents, following a method recommended by Sun et al. [40]. Based on five replicate analyses, average arsenic concentration determined by the spectrofluorimetric method was in an excellent agreement with the certified values. The results are given in Table 4.

\subsection{Determination of Arsenic in Some Ground and Environmental Water Samples of Bangladesh}

Each filtered (with Whatman No. 40) ground and environmental water samples (25-mL) contained in a 50-mL Pyrex beaker were added 1-mL of concentrated $\mathrm{H}_{2} \mathrm{SO}_{4}$ and 2-mL of concentrated $\mathrm{HNO}_{3}$ in the presence of freshly prepared excess ammonium persulfate solution in a fume cupboard to oxidize arsenic (III) to arsenic $(\mathrm{V})$ and the mixture was heated on a hot plate until white fumes of sulfur trioxide, following a method recommended by Greenberg et al. [41]. The solution was cooled and neutralized with dilute $\mathrm{NH}_{4} \mathrm{OH}$ solution in presence of 1 - 2-mL of $0.01 \%(\mathrm{w} / \mathrm{v})$ EDTA solution. Resulting solution was then filtered through a Whatman No. 40 filter paper and quantitatively transferred into a 25-mL calibrated flask and made up to the mark with de-ionized water.

An aliquot $(1-2-\mathrm{mL})$ of this water sample was pipetted into a $10-\mathrm{mL}$ calibrated flask and the arsenic content was determined as described under the general procedure using tartrate or EDTA as masking agent. The results of water analyses by the spectrofluorimetric method were found to be excellent agreement with those obtained by the AHG-AAS and ICP-OES. The results of analyses of ground and environmental water samples from various sources for arsenic are shown in Table 5 and Table 6, respectively.

Most spectrofluorimetric methods for determination of arsenic in natural and sea-water require preconcentration or standard addition of arsenic [42]. The concentration of arsenic in natural and sea water is a few $\mathrm{ngL}^{-1}$ in some developed countries [42].

\subsection{Determination of Arsenic in Some Biological Samples}

Human blood or milk $(2-3-\mathrm{mL})$ or urine $(10-20-\mathrm{mL})$ or hair $(3-5-\mathrm{g})$ or nail (1-2-g) sample was taken into a 100-mL micro-Kjeldahl flask. A glass bead and $10-\mathrm{mL}$ of concentrated nitric acid were added, and the flask was placed on the digester under gentle heating. The sample was digested in the presence of an excess freshly prepared ammonium persulfate solution $(2-\mathrm{mL}$ of $2 \% \mathrm{w} / \mathrm{v})$ to oxidize arsenic (III) to arsenic (V) according to the method recommended by Stahr [43]. As the heating process continued 1- $\mathrm{mL}$ of $\mathrm{H}_{2} \mathrm{SO}_{4}$ is added and heated for about 0.5 hour to dense white fumes of sulfur trioxide. When the initial brisk reaction was completed, the solution was removed and cooled at room temperature and neutralized with dilute $\mathrm{NH}_{4} \mathrm{OH}$ solution in presence of $1-2-\mathrm{mL}$ of 
$0.01 \%(\mathrm{w} / \mathrm{v})$ EDTA solution. Resulting solution was then filtered through a What-man No. 40 filter paper and quantitatively transferred into a $25-\mathrm{mL}$ calibrated flask and made up to the mark with de-ionized water.

A suitable aliquot $(1-2-\mathrm{mL})$ of the final solution was pipetted out into a $10-\mathrm{mL}$ calibrated flask and the arsenic content was determined as described under the general procedure using EDTA or tartrate as masking agent. The results of biological analyses by the spectrofluorimetric method were found to be in excellent agreement with those obtained by AHG-AAS. The results are shown in Table 7.

The abnormally high value for the arsenicosis patient is probably due to the involvement of high arsenic concentration with $\mathrm{Fe}$ as $\mathrm{S}$. The occurrence of such high arsenic contents is also reported in arsenicosis patients from some other countries [44].

\subsection{Determination of Arsenic in Some Surface Soil Samples}

An air-dried homogenized soil sample (10-g) was accurately weighed and placed in a $100-\mathrm{mL}$ micro-Kjeldahl flask. The sample was digested in the presence of an excess oxidizing agent $(2-\mathrm{mL}$ of $2 \%$ freshly prepared ammonium persulfate solution) to oxidize arsenic (III) to arsenic (V) following method recommended by Jackson [45]. As the heating process continued 1- $\mathrm{mL}$ of $\mathrm{H}_{2} \mathrm{SO}_{4}$ is added and heated for about 5 minutes to dense white fumes of sulfur trioxide. The solution was then cooled at room temperature and neutralized with dilute $\mathrm{NH}_{4} \mathrm{OH}$ solution in presence of $1-2-\mathrm{mL}$ of $0.01 \%$ (w/v) EDTA solution. The content of the flask was then filtered through a Whatman No. 40 filter paper and quantitatively transferred into a $25-\mathrm{mL}$ calibrated flask and made up to the mark with de-ionized water.

A suitable aliquot $(1-2-\mathrm{mL})$ of the final solution was pipetted out into a 10 - $\mathrm{mL}$ calibrated flask and the arsenic content was determined as described under the general procedure using tartrate or EDTA as masking agent. The arsenic content was then determined by the above procedure and quantified from a calibration graph prepared concurrently. The average value of arsenic in the Chittagong region surface soil was found to be $4.74-\mathrm{mgkg}^{-1}$. The results are shown in Table 8.

\subsection{Determination of Arsenic in Some Vegetables, Food and Fruit Samples}

The vegetables and fruit samples collected prior to the determination were pretreated in the following way: Edible portion of samples was first washed clean with tap water followed by rewashing with de-ionized water. After removing de-ionized water from the surface of vegetables and fruits, the samples were cut into small pieces and dried at $65^{\circ} \mathrm{C}$ in oven. An air-dried vegetables and fruits samples (10-g) were ground in a mortar and taken in a $100-\mathrm{mL}$ micro-Kjeldahl flask in presence of excess oxidizing agent and digested following a method recommended by Stahr [43] and 10-mL of concentrated nitric acid were added, 
and the flask was placed on the digester under gentle heating. When the initial brisk reaction was over, the solution was removed and cooled at room temperature. 1-mL volume of concentrated sulfuric acid was added carefully, followed by the addition of $2-\mathrm{mL}$ of concentrated HF, and heating was continued for at least $1 / 2 \mathrm{hr}$ and then cooled. In the resulting solution 2 -mL of $2 \%(\mathrm{w} / \mathrm{v})$ of freshly prepared ammonium persulfate is added. The mixture of each foodstuff was heated below the boiling point for 5 - 10 min to oxidize arsenic (III) to arsenic (V). The solutions were then cooled and neutralized with dilute $\mathrm{NH}_{4} \mathrm{OH}$ in presence of 1 2 - $\mathrm{mL}$ of $0.01 \%(\mathrm{w} / \mathrm{v})$ EDTA solution. The resulting solution was filtered through a Whatman No. 40 filter paper and quantitatively transferred into a $25-\mathrm{mL}$ calibrated flask and mixed well and made up to the mark with de-ionized water.

The food samples used were rice, wheat and corn and these were used under dry conditions. Each sample was first ground in a mortar. Corn and fruit samples (2-g) or rice and wheat samples (1-g) were weighed accurately and placed in a porcelain crucible and charred in an electric furnace; the sample was ashen at $555^{\circ} \mathrm{C}$ in a muffle furnace in presence of excess oxidizing agent following a method recommended by Mitra [39]. To it, $2.0-\mathrm{mL}$ of $\mathrm{HCl}$ and $10-\mathrm{mL}$ of water were added to the ash. The mixture of each foodstuff was heated with $2-\mathrm{mL}$ of $2 \%(\mathrm{w} / \mathrm{v})$ freshly prepared ammonium persulfate was added below the boiling point for 5 - 10 min the boiling to complete oxidation from As(III) to As(V). The solutions were cooled and neutralized with dilute $\mathrm{NH}_{4} \mathrm{OH}$ in presence of 1 $2-\mathrm{mL}$ of $0.01 \%(\mathrm{w} / \mathrm{v})$ EDTA solution and filtered. The resulting solution was quantitatively transferred into a $25-\mathrm{mL}$ calibrated flask and mixed well and made up to the mark with de-ionized water.

A suitable aliquot (1-2-mL) of the final digested solution was pipetted into a 10 -mL calibrated flask and the arsenic content was determined as described under the general procedure using tartrate as masking agent. High value of arsenic for carrot (Daucus carota) is probably due to the involvement of high arsenic concentration in soil. The results of food and vegetables analyses by spectrofluorimetric method were found to be in excellent agreement with those obtained by ICP-OES. The results are shown in Table 9.

\subsection{Determination of Arsenic (III) and Arsenic (V) Speciation in Mixtures}

Suitable aliquots (1 - 2-mL) of arsenic (V + III) mixtures (preferably 1:1, 1:5, 1:10) were taken in a 250-mL Pyrex conical flask. A few drops (3 - 5 drops) of 4 $\mathrm{M} \mathrm{H}_{2} \mathrm{SO}_{4}$, and $5-10-\mathrm{mL}$ of $2 \%(\mathrm{w} / \mathrm{v})$ freshly prepared ammonium persulfate were added to oxidize trivalent arsenic to pentavalent arsenic and the mixture was heated gently with further addition of $10-\mathrm{mL}$ water, if necessary, for $5 \mathrm{mi}-$ nutes to drive off the excess persulfate, then the mixture was cooled to room temperature $(25 \pm 5)^{\circ} \mathrm{C}$. The reaction mixture was then cooled and neutralized with dilute $\mathrm{NH}_{4} \mathrm{OH}$ in presence of $3-5-\mathrm{mL}$ of $0.01 \%(\mathrm{w} / \mathrm{v})$ EDTA solution. The solution was transferred quantitatively into a $25-\mathrm{mL}$ volumetric flask and $2.5-\mathrm{mL}$ of $3.77 \times 10^{-4} \mathrm{M}$ PTQA reagent solution was added followed by the addition of 
2.5-mL of $0.5 \mathrm{M} \mathrm{H}_{2} \mathrm{SO}_{4}$. It was made up to the mark with de-ionized water. The fluorescence intensity was measured then being cooled at room temperature (25 $\pm 5)^{\circ} \mathrm{C}$, at $365 \mathrm{~nm}$ when excited at $303 \mathrm{~nm}$, against a reagent blank. The total arsenic content was calculated with the help of a calibration graph prepared concurrently.

An equal aliquot $(1-2-\mathrm{mL})$ of the above arsenic $(\mathrm{V}+\mathrm{III})$ mixture was taken into a $250-\mathrm{mL}$ conical flask. The solution was neutralized with dilute $\mathrm{NH}_{4} \mathrm{OH}$ in presence of $3-5-\mathrm{mL}$ of $0.01 \%(\mathrm{w} / \mathrm{v})$ EDTA solution. After, the content of the beaker was transferred quantitatively into a $25-\mathrm{mL}$ volumetric flask, $2.5-\mathrm{mL}$ of $3.77 \times 10^{-4} \mathrm{M}$ PTQA reagent solution was added, followed by the addition of 2.5-mL of $0.5 \mathrm{M} \mathrm{H}_{2} \mathrm{SO}_{4}$. It was made up to the mark with de-ionized water. After 2 min the fluorescence intensity was measured following the general procedure at $365 \mathrm{~nm}$ when excited at $303 \mathrm{~nm}$ against a reagent blank, as before. The arsenic concentration was calculated in $\mu \mathrm{gL}^{-1}$ or $\mathrm{ngL}^{-1}$ with the aid of a calibration graph. This gives a measure of arsenic (V) originally present in the mixture. This value was subtracted from that of the total arsenic to determine the arsenic (III) present in the mixture. The results of the assessment of speciation of $\mathrm{As}(\mathrm{V})$ and $\mathrm{As}(\mathrm{III})$ were found to be highly reproducible. The occurrence of such reproducible results is also reported for different oxidation states of arsenic [46]. The results of a set of determination are given in Table 10.

\section{Conclusions}

A new simple, rapid, ultra-sensitive, highly selective and inexpensive spectrofluorimetric method with the arsenic-PTQA system was developed for the determination of arsenic in some real, environmental, biological, food, vegetables and soil samples, for continuous monitoring to establish the pico-trace levels of arsenic in different samples matrices. Compared with other methods [12]-[32] in the literature Table 1 of the proposed method has several remarkable analytical characteristics:

Firstly, the proposed method is highly sensitive that the amount, in $n g L^{-1}$, of arsenic can be determined without pre-concentration in diluted biological solutions.

Secondly, the low detection limit, $0.1-\mathrm{ngL}^{-1}$ i.e. $\mathrm{pgg}^{-1}\left(10^{-12} \mathrm{~g} \mathrm{~g}^{-1}\right)$ levels can be measured without pre-concentration or standard addition method. The proposed method is very simple, rapid, and stable. The reaction of arsenic with PTQA is instantaneous, so it does not involve any stringent reaction conditions and offer the advantages of high stability of fluorescence intensity (over $24 \mathrm{~h}$ ) at room temperature $\left(25^{\circ} \mathrm{C} \pm 5^{\circ} \mathrm{C}\right)$, reliable and reproducible.

Thirdly, the method has added the advantages of determining individual amounts of arsenic (III) and arsenic (V). With suitable masking agents, the reaction can be made highly selective and better reproducibility has been achieved ( $s_{\mathrm{r}}$ $=0 \%-2 \%)$.

Finally, the proposed method using PTQA in aqueous solutions not only is 
one of the most sensitive methods for the determination of arsenic but also is excellent in terms of selectivity, simplicity and precision (RSD: $0 \%-2 \%$ ). Therefore, this method can be successfully used in routine analysis of pico-trace amounts of arsenic in real, environmental, biological, food, vegetables and soil samples. It is a new method needs neither heating nor extraction to organic phase, works satisfactorily and could be an alternative to standard method for the rapid determination of arsenic in a wide variety of sample matrices and found superior to existing spectrofluorimetric methods reported in different literature [12]-[32].

\section{Acknowledgements}

We are thankful to the Authorities of Chittagong Medical College Hospital and Chittagong Treatment Hospital for supplying biological samples, to the Authorities of BNO lubricants, Chittagong to permit us for analyzing Biological, Food and Pharmaceutical Samples by ICP-OES and also grateful to the Department of Chemistry, University of Chittagong for providing us all the logistic supports for completion of our Research Work.

\section{Conflicts of Interest}

All authors report no conflicts of interest relevant to this article.

\section{References}

[1] Ahmed, M.J. (2003) Arsenic Contamination of Underground Water in Bangladesh: Cause, Effect, Speciation, Determination and Remedy. Pakistan Journal of Analytical Chemistry, 4, 133-136.

[2] Hussam, A. and Munir, A.K.M. (2008) Arsenic Filters for Groundwater in Bangladesh: Toward a Sustainable Solution. National Academy of Engineering, 38, 14-20.

[3] Tareq, S.M., Safiullah, S., Anwar, H.M., Rahman, M.M. and Ishizuka, T. (2003) Arsenic Pollution in Groundwater of Bangladesh. The Science of Total Environment, 313, 213-226. https://doi.org/10.1016/S0048-9697(03)00266-3

[4] Anwar, H.M., Akai, J., Mostafa, K.G.M., Safiullah, S. and Tareq, S.M. (2002) Arsenic Poisoning in Groundwater: Health Risk and Geochemical Sources in Bangladesh. Environment International, 27, 597-605. https://doi.org/10.1016/S0160-4120(01)00116-7

[5] Ahmed, M.J. and Hasan, M.J. (1999) Non-Extractive Spectrophotometric Method for Determination of Arsenic and Its Application to Environmental, Biological and Soil Analysis. Research Journal of Chemistry and Environment, 3, 9-20.

[6] Ahmed, M.J. and Rahman M.Z. (1995) Spectrophotometric Method for Determination of Arsenic and Its Application to Chemical, Industrial, Environmental, Biological and Soil Analysis. Chemical and Environmental Research, 4, 227-335.

[7] Ahmed, M.J., Stalikas, C.D., Veltsistas, P.G., Tzouwara-Karayanni, S.M. and Karayannis, M.I. (1997) Simultaneous Spectrofluorimetric Determination of Selenium (IV) and (VI) by Flow Injection Analysis. Analyst, 122, 221-226. https://doi.org/10.1039/a606357h

[8] Ahmed, M.J., Tazul, I.M. and Hossain, F. (2018) A Highly Sensitive and Selective 
Spectrofluorimetric Method for the Determination of Manganese at Nanotrace Levels in Some Real, Environmental, Biological, Soil, Food and Pharmaceutical Samples Using 2-( $\alpha$-pyridyl)-thioquinaldinamide. RSC Advances, 8, 5509-5522. https://doi.org/10.1039/C7RA12762F

[9] Porter, H.D. (1954) The Willgerodt Reaction Applied to $\alpha$ - and $\gamma$-Alkylpyridines. Journal of America Chemical Society, 76, 127-132. https://doi.org/10.1021/ja01630a035

[10] Pal, B.K., Ahmed, M.J. and Chakrabarty, A.K. (1988) 2-( $\alpha$-pyridyl)thioquinaldinamide: A Novel Fluorimetric Reagent in Inorganic Trace Analysis: Part 2. A Simple Selective Determination of Selenium (IV) at Ultra-Trace Levels. Analytica Chimica Acta, 206, 345-349.

[11] Pal, B.K., Ahmed, M.J. and Chakrabarty, A.K. (1989) 2-( $\alpha$-Pyridyl)-thioquinaldinamide (PTQA): A Novel Fluorimetric Reagent in Inorganic Trace Analysis. I: The Nonextractive, Nonquenching Fluorescent Method for the Determination of Chromium (VI). Mikrochimica Acta, 1, 393-401.

[12] Yuan, B., et al. (2010) Fluorimetric Determination of Arsenite and Arsenate in Water Using Fluorescein and Iodine. International Journal of Environmental Analytical Chemistry, 67, 31-40.

[13] Hosseini, M.S. and Belador, F. (2014) A Novel Spectrofluorometric Method for the Determination of Arsenic in Human Hair Using $\mathrm{Dy}_{2} \mathrm{O}_{3}$-Doped $\mathrm{CeO}_{2}$ Nanoparticles. Analyst, 139, 5007. https://doi.org/10.1039/C4AN00746H

[14] Zhu, R.H. and Chen, L.H. (2011) Spectrofluorimetric Determination of Arsenic (III) in Water Samples. Asian Journal of Chemistry, 23, 5271-5278.

[15] Tang, G., et al. (2015) Determination of Arsenic (III) Based on the Fluorescence Resonance Energy Transfer between CdTe QDs and Rhodamine 6G. Royal Society of Chemistry Advances, 5, 17519-17531. https://doi.org/10.1039/C4RA16789A

[16] Fan, J., Kong, J., Ye, C. and Feng, S. (2006) Inhibitory Kinetic Fluorimetric Determination of Trace Arsenic (III) in the Presence of Arsenic (V). Chinese Journal of Analysis Laboratory, 11, 42-45.

[17] Biswas, S., Chowdhury, B. and Ray, B.C. (2004) Analytical Study of an Environmentally Hazardous Element, Arsenic, by Indirect Spectrofluorimetric Method in Diverse Fields. Analytical Letters, 9, 1965-1976. https://doi.org/10.1081/AL-120039439

[18] Manap, M.RA., Yusof, N.A., Siti, M.M.N. and Faujan, A.B.H. (2013) Spectrofluorimetric Determination of Arsenic (III) Using Dansylated Peptide. Asian Journal of Chemistry, 25, 4195-4203. https://doi.org/10.14233/ajchem.2013.13890

[19] Anjali, P., Jana, N.R., Sau, T.K., Bandyopadhyay, M. and Pal, T. (1996) Spectrofluorimetric Determination of Arsenic in Water Samples. Analytical Communications, 33, 315-321. https://doi.org/10.1039/ac9963300315

[20] Liu, B.S., Gao, J., et al. (2006) Fluorescence Resonance Energy Transfer Quenching Method for Determination of Arsenic with Acridine Orange-Rhodamine B. Spectroscopy and Spectral Analysis, 26, 306-308.

[21] Li, G., et al. (2009) The Molecular Resonance Fluorescence Method for Determination of Arsenic in Hair Samples. Spectrochimica Acta, 72, 811-821. https://doi.org/10.1016/j.saa.2008.11.031

[22] Hu, S.R., Yang, T.L., Liu, Q.Y. and Zhou, L.H. (2006) Fluorescence Quenching Method for the Determination of Arsenic with $\mathrm{H}_{2} \mathrm{O}_{2}-2,3,4,9-$ Tetrahydrogen-9-Hydroxy-1, 10-Anthraquinone System. Journal of Instrumental Analysis, 6, 60-66. 
[23] Lei, Z.Y. (2007) Determination of Trace Arsenic by the Fluorescence Kinetic Analytic Method. Chinese Journal of Analytical Chemistry, 6, 21-32.

[24] Zhao, Q., Chen, L.H. and Zhu, R.H. (2012) Determination of Trace Arsenic in Environmental Water Samples by Inhibitory Fluorescence Quenching Method. Chinese Journal of Analysis Laboratory, 5, 225-234.

[25] Feng, S.L., Tang, A.N. and Fan, J. (2001) A Fluorescence Quenching Method for Determination of Arsenic. Chinese Journal of Analytical Chemistry, 29, 1315-1325.

[26] Fan, C., Li, X., Gao, Q., Fan, T. and Xia, B. (2009) Fluorophotometric Determination of Trace Amounts of Arsenic(III) in Water by Its Fluorescence Quencing Action. Journal of Physical Testing and Chemical Analysis, 7, 237-245.

[27] Zhang, H.M., Zhang, X.H. and Li, D.C. (2009) The Detergency of the Mixed System of LAS and Alkyl Diphenyloxide Disulphonate. Chemical Industry Times, 9, 35-46.

[28] Vaishanav, S., Korram, J., Pradhan, P., Chandraker, K., Nagwanshi, R., Ghosh, K. and Satnami, M. (2017) Green Luminescent CdTe Quantum Dot Based Fluorescence Nano-Sensor for Sensitive Detection of Arsenic (III). Journal of Fluorescence, 27, 781-788. https://doi.org/10.1007/s10895-016-2011-0

[29] Hu, X., Zhang, Y., Luo, J., Wang, T., Lian, L. and Ding, Z. (2011) Bioaccessibility and Health Risk of Arsenic, Mercury and Other Metals in Urban Street Dusts from a Mega-City, Nanjing, China. Environmental Pollution, 159, 1215-1222. https://doi.org/10.1016/j.envpol.2011.01.037

[30] Lomonte, C., Currell, M., Morrison, R.J., McKelvie, I. and Kolev, S. (2007) Sensitive and Ultra-Fast Determination of Arsenic (III) by Gas-Diffusion Flow Injection analysis with Chemiluminescence Detection. Analytica Chimica Acta, 583, 72-80. https://doi.org/10.1016/j.aca.2006.09.049

[31] Song, G. (1997) Determination of Phosphorus, Arsenic and Silicon by Flow Injection Fluorimetry. Chinese Journal of Analytical Chemistry, 25, 1404-1419.

[32] Cheng, D. and Zhang, H. (2002) Study on the Determination of Arsenic by Catalytic Fluorimetry. Analytical Laboratory, 2, 21-29.

[33] Jeffery, G.H., Bassett, J., Mendham, J. and Denney, R.C. (1994) Vogel's Textbook of Quantitative Chemical Analysis. ELBS of 5th Edition, Bath Press Ltd., London, 275-279.

[34] Mukharjee, A.K. (1970) Analytical Chemistry of Zirconium and Hafnium. Pergamon Press, New York, 12-32.

[35] Pal, B.K. and Chowdhury, B. (1984) Triazene-N-Oxides as New Type of Fluorimetric Reagents Mikrochim. Acta, 11, 121-129. https://doi.org/10.1007/BF01201540

[36] Ojeda, C.B., Torres, A.G., Rojas, F.S. and Pavon, J.M.C. (1987) Fluorimetric Determination of Trace Amounts of Gallium in Biological Tissues. Analyst, 112, 1499-1506. https://doi.org/10.1039/AN9871201499

[37] Ahmed, M.J., Stalikas, C.D., Veltsistas, P.G., Tzouwara-Karayanni, S.M. and Karayannis, M.I. (1997) Simultaneous Spectrofluorimetric Determination of Selenium (IV) and (VI) by Flow Injection Analysis. Analyst, 122, 221-226. https://doi.org/10.1039/a606357h

[38] Pal, B.K., Ahmed, M.J. and Chakraborty, A.K. (1990) 2-( $\alpha$-Pyridyl)thioquinaldinamide: A Spectrofluorimetric Reagent in Inorganic Trace Analysis. Part III. Determination of Manganese in Industrial and Environmental Samples. Analyst, 115, 439-443. https://doi.org/10.1039/AN9901500439

[39] Mitra, S. (2003) Sample Preparation Techniques in Analytical Chemistry. Wiley-Inter Sciences, Hoboken, 125-162. https://doi.org/10.1002/0471457817 
[40] Sun, C., Yang, J.Y. and Tzeng, S.R. (1999) Rapid Determination of Molybdate in Natural Waters by Coprecipitation and Neutron Activation Analysis. Analyst, 24, 421 426. https://doi.org/10.1039/a809596e

[41] Greenberg, E.A., Clesceri, S.L. and Eaton, D.A. (1992) Standard Methods for the Examination of Water and Wastewater. 3rd Edition, American Public Health Association, Washington DC, 253-268.

[42] Chambon, P., Lound, U. and Ohanian, E. (1993) WHO Guidelines for Drinking Water Quality, Recommendations. 2nd Edition, WHO, Geneva.

[43] Stahr, H.M. (1991) Analytical Methods in Toxicology. 3rd Edition, John Wiley and Sons, New York, 85-94.

[44] Chatterjee, A., Das, D., Mandal, B.K., Chowdhury, T.R., Samanta, G. and Chakrabarti, D. (1995) Arsenic in Ground Water in Six Districts of West Bengal, India: The Biggest Arsenic Calamity in the World. Part 2. Arsenic Concentration in Drinking Water, Hair, Nails, Urine, Skin-Scale and Liver Tissue (Biopsy) of the Affected People. Analyst, 120, 643-651. https://doi.org/10.1039/an9952000917

[45] Jackson, M.L. (1965) Soil Chemical Analysis. Prentice Hall, Englewood Cliffs, 326-332.

[46] https://www.ncbi.nlm.nih.gov/pubmed/24090406 